\title{
A COMPREHENSIVE REVIEW OF PHOTOVOLTAIC DEVICES BASED ON PEROVSKITES
}

\author{
Iyasele, E. O.
}

Mechanical Engineering Department, Michael Okpara University of Agriculture, Umudike, Abia State, Nigeria

Phone: +2348135359855 Email: edgaromons2003@yahoo.com,eo.iyasele@mouau.edu.ng

\begin{abstract}
Perovskite solar cells (PSCs) though in its development stage, has been of interest to Scientists receiving considerable attention in recent years as a promising material capable of developing high performance photovoltaic devices at low cost. Owing to their solution processability, broad spectrum solar absorption, low non-radiative recombination losses, etc., PSCs provide numerous advantages over most thin film absorber materials. Due to the substantial improvement of Power Conversion Efficiency (PCE) of these materials, photovoltaic efficiency has reached prestigious position (approx. $20.1 \%$ ) within the last 5 years. In this review article, we discuss the current state of the Art for photovoltaic devices based on Perovskites, highlighting the underlying phenomenon, synthesis, challenges, comparison to other technologies and future outlook. We emphasized the importance of Perovskite film formation and qualities in achieving highly efficient photovoltaic devices. The flexibility and simplicity of Perovskite fabrication methods allows the use of mesoporous and planar device architectures. A variety of processing techniques are currently employed to form the highest quality $\mathrm{CH}_{3} \mathrm{NH}_{3} \mathrm{PbX}_{3}$ films resulting to high performance PSC devices which include stoichiometry, thermal annealing, solvent engineering, additives and environmental control. In this review, we outlined and discussed the challenges of PSCs including its stability issues, hysteresis effects, and ion migration effects. Possible ways overcoming these challenges and improvement on the stability of PSCs so far were also addressed.
\end{abstract}

Keywords: cell, device, efficiency, film, materials, Perovskites, phase, photovoltaic, solution, structure.

LICENSE: This work by Open Journals Nigeria is licensed and published under the Creative Commons Attribution License 4.0 International License, which permits unrestricted use, distribution, and reproduction in any medium, provided this article is duly cited.

COPYRIGHT: The Author(s) completely retain the copyright of this published article.

OPEN ACCESS: The Author(s) approves that this article remains permanently online in the open access (OA) mode.

QA: This Article is published in line with "COPE (Committee on Publication Ethics) and PIE (Publication Integrity \& Ethics)". 


\section{INTRODUCTION}

World Energy resources 2016 reported that 1.3 billion people globally and 93 million in Nigeria have no access to electricity (world energy resources, 2016). Yet, every hour the sun beams more energy onto the Earth than it requires to satisfy the global energy needs for an entire year (National Geographic Report, 2017). Thereby offering a solution to the increasing concern of energy shortage, global warming, and greenhouse gases by fossil fuels (oil, natural gas and coal). Solar energy is the most abundant and cleanest form of energy for our energy- starved planet (Mohammed et al., 2015). It remains a foremost energy resource with unlimited capacity to solve man's numerous energy needs (Abodunrin et al., 2015). Surprisingly, most major solar installation has been in regions with relatively less solar resources (Europe and China) while potential in high resources regions (Africa and Middle East) remain untapped (World Energy resources, 2016). However, in regions other than Africa (like south-western United States, Central and South America, Middle East, the desert plains of India, Pakistan, Australia, etc.), such potential is only limited to generate 125 Gigawatt hours (GWh) from a $1 \mathrm{~km}^{2}$ land area (Adaramola, 2014). A deliberate transition from conventional sources of electricity energy to renewable and environmentally friendly sources is critical for national development, though recent developments show the Nigerian government backsliding in adopting renewable energy technologies (Akuru, et al., 2017).

The Energy Information Administration (EIA) of the United States government has quoted that, about $10 \%$ of the worlds marketed energy consumption is from renewable energy. This $10 \%$ comprises of solar, geothermal, hydropower, wind, nuclear, biomass, and biofuel with the remaining 90\% from fossil fuels (Chang $e t$ al., 2010). With the world energy consumption expected to increase by $71 \%$ from 2003 to 2030 , it becomes a fact that for the next two to four decades, fossil fuels are likely to remain the primary sources of energy in the world. Currently, the world's fossil fuels are being consumed more rapidly than they are being created, thus, there is a pressing need for alternative energy sources that are both renewable and environmentally benign (Mao et al., 2007, Chang et al., 2010; Elano et al., 2009). Projected increase in global energy demand, predicted to be as high as $1 \mathrm{Gw} / \mathrm{day}$, will place significant strains on current energy infrastructure (Espinosa et al., 2012). This looming challenge, coupled with depleting traditional fossil fuel-based energy sources with the threat of climate change, require the development of renewable energy technologies (Wang et al., 2016). Among the renewable energy approaches, photovoltaic (PV) presents a promising route. The current photovoltaics landscape is dominated by silicon solar cells, though these cells are constrained by fundamental cost barriers, such as high temperature processing. However, Green et al., 2012 reported that silicon solar cells have advanced tremendously both in terms of cost of production and efficiency over the past four decades. An alternative to these cells is the third-generation photovoltaic devices (a technology that promises a combination of lower cost and ease of synthesis with a better energy payback matrix) developed from various dye sensitizers, organic and hybrid (organic and inorganic) materials (Seelam and Lingamaller, 2016). Ever since the discovery of the photovoltaic effect by the French Physicist Edmond Bec- querel in 1839, a myriad of emerging solar technologies has been developed, with three of the most highly researched being organic photovoltaics (OPVs), dye-sensitized solar cells (DSSCs), and recently, Perovskite solar cells (Ugwoke, 2014). Among these materials, organometallic halide Perovskites offer captivating prospects owing to their solution processability, broad solar absorption spectrum, low non-radiative recombination losses, etc. Due to the substantial improvement of Power Conversion Efficiency (PCE) of these materials, photovoltaic efficiency has reached prestigious position (approx. $20.1 \%$ ) within 5 years.

Though in its development stage, Perovskite solar cells (PSC) has been of much interest to 
Scientists. The "Science" magazine touted it as one of the top scientific breakthroughs of 2013 (Dawn, 2016). However, there are issues which need to be resolved in the commercialization of Perovskites and limits is application. (Seelam and Lingamellm, 2016). Hence, this comprehensive review presents the current state of the Art of photovoltaic devices based on Perovskites, highlighting the underlying phenomenon, synthesis, challenges, comparison to other technologies and future outlook.

\section{PHENOMENA}

Though a detailed overview of the historical evolution of PSC performance, occurring over a short time period, can be found in several review articles (Snaith 2013; Leijtens et al.,2015; Yu and Sun, 2015, and Rong et al.,2015), Perovskites have being known over a century ago (Green et al., 2014), they received attention only when Miyasaka et. al. used methylammonium lead halide (Perovskite) as a light harvesting material in excitonic solar cells (Kojima et al., 2009). This group utilized Perovskite as sensitizers in dye sensitized solar cells (DSSC) and achieved the solar-to-power conversion efficiency of 3.2\% for $\left(\mathrm{CH}_{3} \mathrm{NH}_{3}\right) \mathrm{PbBr}_{3}$ and $3.8 \%$ $\left(\mathrm{CH}_{3} \mathrm{NH}_{3}\right) \mathrm{PbI}_{3}$ (Kojima et al., 2009). However, instability of these devices due to the degradation of Perovskites in liquid electrolyte containing lithium halide prompted Park et al. in 2011 to develop the quantum-dot sensitized solar cells using Perovskite $\left(\mathrm{CH}_{3} \mathrm{NH}_{3}\right) \mathrm{PbI}_{3}$ sensitizers (Im et al,. 2011). But these devices reduced the performance of solar cell in a short span of time due to the dissolution of halides in liquid electrolyte (Im et al., 2011). In order to avoid corrosive liquid electrolyte in Perovskite DSSC, Kim et al., developed the solid-state electrolyte, spiro-OMeTAD (2,2 1 7,71-tetrakis (N,N-di-p-methoxyphenylamine)- 9,91'-spirobiflourence), which can act as a hole transporting material (HTM) (Kim et al.,2012).

The architecture of Perovskite solar cells was derived from the dye sensitized solar cell (DSSC) technology (Wang et al., 2016). The traditional architecture of DSSCs consisted of a porous $\mathrm{TiO}_{2} \mathrm{scaffold}_{\text {, }}$ sensitized by a dye and infiltrated by a liquid electrolyte. As regards the dye, Kojima et al. (2009) investigated $\mathrm{CH}_{3} \mathrm{NH}_{3} \mathrm{PbBr}_{3}$ and $\mathrm{CH}_{3} \mathrm{NH}_{3} \mathrm{PbI}_{3}$ as an alternative to replace it. This however yielded moderate success (Kojima et al., 2009; Kojima et al., 2006). Based on the inherent instability of these devices, Lee et al. in 2012 attempted to replace the $\mathrm{TiO}_{2}$ scaffold, used to transport electrons, with an insulator $\left(\mathrm{Al}_{2} \mathrm{O}_{3}\right)$ (Lee et al., 2012). This demonstrated for the very first time that Perovskite material could effectively transport electrons without the underlying $\mathrm{TiO}_{2}$ layer. With this insight, the demonstration of a planar geometry solar cell with a Perovskite thin film as the absorber layer evolved (Liu et al., 2013). A high efficiency with this device structure was however achieved.

\section{WHAT ARE PEROVSKITES?}

Perovskite is a type of mineral that is chemically found on the earth crust. It was first discovered in the Ural Mountains and was named after a Russian noble man and mineralogist, Lev Perovski (founder of the Russian Geographical Society) (Dawn, 2016). The Perovskite solar cells have the same structure of the Perovskite mineral, hence named Perovskite solar cells. A Perovskite structure is anything that has the generic form $\mathrm{ABX}_{3}$ and the crystallographic structure as Perovskite (the mineral).

Depending on the atoms or molecules used in the structure, Perovskites may obtain a set of interesting properties like superconductivity, spintronics and catalytic properties. Hence, scientists and researchers find Perovskites as exciting playground for physicists, chemists and material scientists. 


\section{CRYSTAL STRUCTURE}

Perovskite are a family of materials with the crystal structure of calcium titanate, that is, $\mathrm{ABX}_{3}$ (Muhammad et al., 2015). There are numerous materials which adopt this structure with exciting applications based on their thermoelectric, insulating, semi conducting, piezoelectric, conducting, antiferromagnetic and superconducting properties (Service, 2014). $\mathrm{ABX}_{3}$ describes the crystal structure of Perovskite class of materials, where A and B are cations and $\mathrm{X}$ is an anion of different dimensions with $\mathrm{A}$ being larger than $\mathrm{X}$. Crystal structure of Perovskites is illustrated in figure 2.1 below:
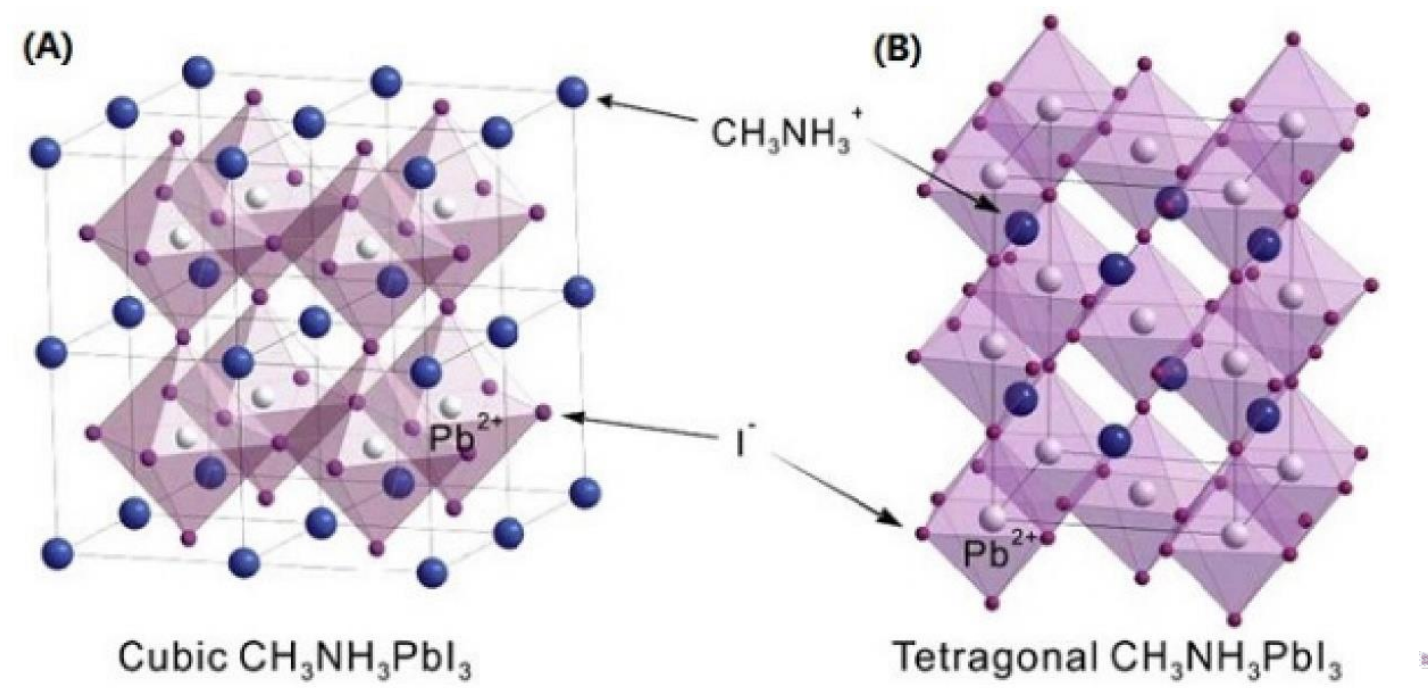

Figure 1: Crystal structure of Perovskite

Source: Shiqiang and Walid (2016).

The crystal structure of Perovskite can be alternatively viewed as corner-linked $\mathrm{BX}_{6}$ octahedral with interstitial $\mathrm{A}$ cation. Its crystallographic stability and apparent structure can be deduced by considering a Goldschmidt tolerance factor $\mathrm{t}$ and an octahedral factor $\mathrm{N}$. The tolerance factor $\mathrm{t}$ is defined as the ratio of the distance $\mathrm{A}-\mathrm{X}$ to the distance $\mathrm{B}-\mathrm{X}$ in an idealized solid sphere model as shown in equation (1) below:

$$
t=\left(R_{A}+R_{X}\right) /\left[\sqrt{ } 2\left(R_{B}+R_{X}\right)\right]
$$

Where $R_{A}, R_{B}$ and $R_{X}$ are the ionic radii of the corresponding ions.

The octahedral factor $\mu$ is defined as the ratio $\mathrm{R}_{\mathrm{B}} / \mathrm{R}_{\mathrm{X}}$. For halide Perovskites $(\mathrm{X}=\mathrm{F}, \mathrm{Cl}, \mathrm{Br}$ and $\mathrm{I}), 0.81<\mathrm{t}<1.11$ and $0.44<\mu<0.90$ are the typical values. Narrower range of $\mathrm{t}$ values from 0.89 to 1.0 dictates cubic structure, while lower values of $\mathrm{t}$ stabilizes as a less symmetric tetragonal and orthorhombic structure.

In case of $\mathrm{ABX}_{3}$, the larger cation $\mathrm{A}$ is considered as an organic cation typically methylammonium $\left(\mathrm{CH}_{3} \mathrm{NH}_{3}{ }^{+}\right)$with $\mathrm{R}_{\mathrm{A}}=0.18 \mathrm{~nm}$ (Li et al., 2008), though ethylammonium $\left(\mathrm{CH}_{3} \mathrm{CH}_{2} \mathrm{NH}_{3}+, \mathrm{Ra}=0.23 \mathrm{~nm}\right)$ and formamidinium $\left(\mathrm{NH}_{2} \mathrm{CH}=\mathrm{NH}_{2}+, \mathrm{R}_{\mathrm{A}}=0.19-0.22 \mathrm{~nm}\right)$ also provide excellent results. Anion $\mathrm{X}$ is an halogen such as iodine with $\mathrm{R}_{\mathrm{x}}=0.220 \mathrm{~nm}$, Bromine $(\mathrm{Br})$ and chlorine $(\mathrm{Cl})$ used in Perovskites with $\mathrm{Rx}=0.196 \mathrm{~nm}$ and $0.181 \mathrm{~nm}$ respectively though in a mixed halide configuration. For cation $B$, Lead $(\mathrm{Pb})$ with $\mathrm{R}_{\mathrm{B}}=0.119 \mathrm{~nm}$ and Tin $(\mathrm{Sn})$ with $\mathrm{R}_{\mathrm{B}}=0.110 \mathrm{~nm}$ have been used for high efficiency in PSCs because of lower theoretical ideal band gaps (Pang 
et al., 2014). Although $\mathrm{Sn}$ has similar band gap with $\mathrm{Pb}$ and in the same group, due to the ease of oxidation and lack of stability, it performs poorly compared to $\mathrm{Pb}$ in efficiency.

\section{TYPES OF PEROVSKITE SENSITIZED SOLAR CELLS}

\section{PEROVSKITE SENSITIZED SOLAR CELLS}

DSSCs are the forerunners of Perovskite solar cells. In search of a more efficient light sensitizers for DSSCs, Miyasaka et. al. reported the first Perovskite sensitized solar cells between 2006 and 2008. $\mathrm{CH}_{3} \mathrm{NH}_{3} \mathrm{PbI}_{3}$ and $\mathrm{CH}_{3} \mathrm{NH}_{3} \mathrm{PbBr}_{3}$ absorbers were employed with an iodide triiodide redox couple or a polypyrrole carbon black composite solid-state hole conductor. Full sun Power Conversion Efficiency (PCE) varying between 0.4 and $2 \%$ was measured for solid-state and liquid electrolyte cells, respectively (Kojima et al., 2006).

Owing to the instability and degradation within minutes of these cells, due to the liquid electrolyte, the idea of adopting a solid-state hole transport medium was born. Kojima et al. in 2006 attempted this but success was only made when Murakami, Miyasaka and Park in collaboration with Gratzel et al. developed the first solid-state Perovskite solar cells employing Spirobifluorene (spiro-OMeTAD) as the hole transporter (kojima et al., 2006). This cell recorded maximum full sun PCE of between 8 and 10\% employing mixed halide Perovskites of iodine and chlorine (Kojima et al., 2009).

\section{MESOPOROUS TIO 2 STRUCTURES}

The first use of hybrid Perovskite absorbers in photovoltaic cells is based on the typical structure of a dyesensitized solar cell, where the Perovskite absorber is self-assembled within the gaps of a porous $\mathrm{TiO}_{2}$ layer formed by sintering nanoparticles (Song et al., 2015). The typical configuration of this type of Perovskite based solar cells FTO / Mesoporous $\mathrm{TiO}_{2}$ /Perovskite / (spiro-OMeTAD) / electrode is as shown below in figure 2

(a)

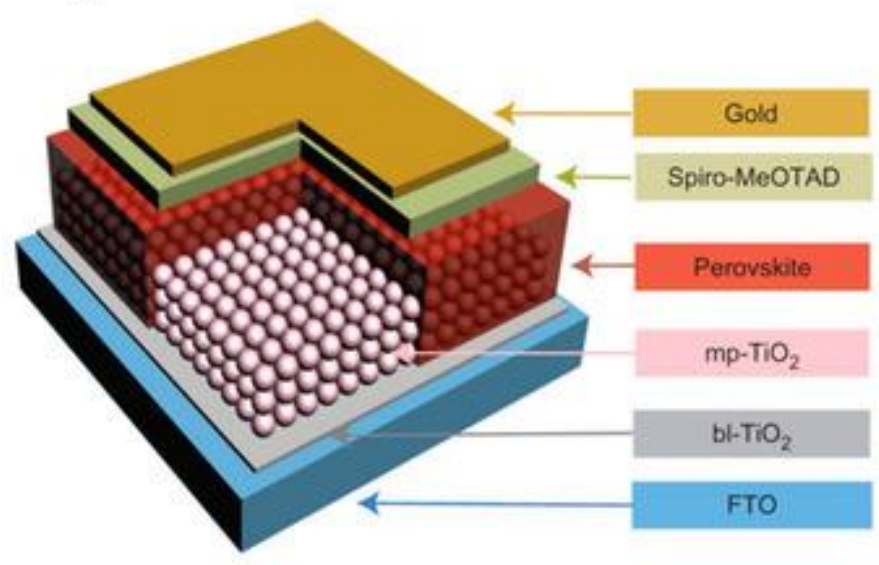

(b)

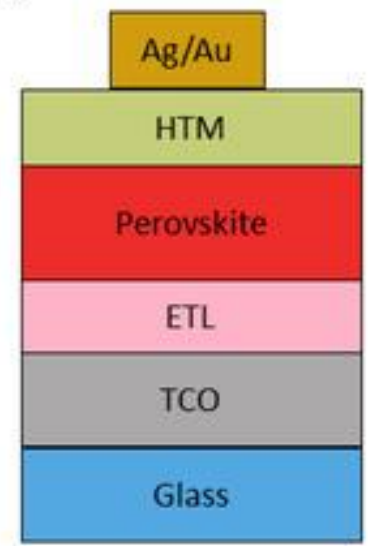

Figure 2: Schematic Diagram and Cross Section of the Mesoporous Structured PSC Device Source: Paola et al. (2017).

In this structure, Perovskite materials are deposited onto Mesoporous $\mathrm{TiO}_{2}$, which is used to facilitate electron transport between the Perovskite absorber and the FTO (fluorine-doped Tin oxide) electrode. A subsequent work demonstrated the replacement of the relatively conductive porous $\mathrm{TiO}_{2}$ with an insulating porous $\mathrm{Al}_{2} \mathrm{O}_{3}$ layer 
(Song et al., 2015). It is however important to note that successful pore-filling in these structures is necessary in order to prevent leakage via the device, which has been an issue for thick Mesoporous structures.

The use of Mesoporous structures as a scaffold to fabricate Perovskite solar cells has led to an increase in device performance from 3.8\% to over 17\% PCE within a few years (Kojima et al., 2009). Just as these structures do not rely on long carrier diffusion length; it is also able to provide a compensation platform for the investigation of new Perovskite materials (Song et al., 2015). While the use of a Mesoporous scaffold requires a comparatively complex device architecture and fabrication process in which many problems could arise, it has consistently delivered high efficiencies that made its use fully worthwhile for laboratory scale investigations (Song et al., 2015).

\section{PLANAR STRUCTURE}

In a planar junction Perovskite solar cell, a several hundred nanometer thick absorber layer, is sandwiched between the electron transport layer (ETL) and hole transport layer (HTL) without a Mesoporous scaffold (Song et al., 2015). These cells can deliver efficiency values of over $15 \%$ despite being under developed for an even shorter period than their Mesoporous counterparts. This architecture offers the advantages of a simplified device configuration and fabrication procedure, and thus, rapidly acquired the interest of the thin film research community. Planar structures are most commonly illuminated from the n-type side, resulting in the structure glass/TCO/ETL/Perovskite/HTL/metal or p-type side, resulting in the inverted structure glass/TCO/HTL/Perovskite/ETL/metal which functions in a superstrate configuration. Owing to its simplified fabrication and ease of deposition, the planar architecture provides a great promise in future applications, including high performance flexible and portable devices (Song et al., 2015).

\section{MESOSUPERSTRUCTURED PSCS (MSSC)}

These are PSC device structures having $\mathrm{CH}_{3} \mathrm{NH}_{3} \mathrm{PbI}_{2} \mathrm{Cl}$ mixed Perovskite, coated with alumina layer in a photovoltaic cell. Bi et al., reported that the PCE of this type of structure reached 10.9\% in 2013 (Bi et al., 2013). They were so called because the photogenerated electrons are not transferred to alumina because of the difference in band edges of alumina and Perovskite active layer, which acts only as a scaffold for carrying the photoactive layer (Muhammed et al., 2015). The scaffold layers afford processing at lower temperatures by excluding high temperatures annealing step as neither generated electron are injected into the Mesoporous layer nor transported. With the advantage of processing at lower temperatures, Lee et al. reported a MSSC/PCE value of $12.3 \%$ (Though $\mathrm{Al}_{2} \mathrm{O}_{3}$ Mesoporous layers was dried at $150^{\circ} \mathrm{C}$ ) (Lee et al.,2012).

\section{HYBRID PEROVSKITE SOLAR CELLS}

An example of a hybrid planar heterojunction solar cell is a device structure based on $\mathrm{TiO}_{2} \mathrm{CH}_{3} \mathrm{NH}_{3} \mathrm{PbI}_{3-\mathrm{X}} / \mathrm{P} 3 \mathrm{HT}$ (poly (3-hexylthiophene)). Such device achieved a better photovoltaic performance when the ITO (indium-dopedTin-oxide) substrate was treated with C60 self-assembled monolayer having an improved PCE of 6.7\%. This was achieved with a significant increase in both Jsc (shunt current density) and Voc (open circuit voltages) (Jeng et al., 2013). The active layer of a hybrid planar heterojunction cell can be sandwich between poly ( $\mathrm{N}, \mathrm{N}^{1}$-bis $(4-$ butylphenyl) - N, $\mathrm{N}^{1}$-bis (phenyl)- benzidine)(poly-TPD) as Hole transporting material layer and electron accepting PCBM layer (Abrusci et al.,2013). A PCE of $12 \%$ was thus reported. 


\section{FLEXIBLE PEROVSKITE SOLAR CELLS}

If the commercialization goal of PSCs must be achieved, further studies on the possibilities of fabricating cells and flexible substrate must be encouraged. However, several works have been done in this field owing to the low temperature solution processability of PSCs. Ability to conform to the contours of the platform holds obvious promises for incorporation of this technology in diverse application (Muhammad et al., 2015). Docampo et al., in 2013 achieved a higher PCE of 10.2\% using device structure ITO / $\mathrm{ZnO}(25 \mathrm{~nm}) / \mathrm{CH}_{3} \mathrm{NH}_{3} \mathrm{PbI}_{3} / \mathrm{Spiro}-\mathrm{MeoTAD}$ /Ag, fabricated using low temperature solution processing techniques (Docampo et al., 2013).

\section{HYBRID MULTIJUNCTION SOLAR CELLS}

Song et al., concluded in the work saying it is anticipated that the demonstration of new solar technologies based on Perovskites, or the integration of an established manufacturing method that uses both Perovskite and existing technologies are particularly promising for the future photovoltaic market (Song et al., 2015). They envisaged a tandem cell configuration where PSCs can be used effectively as a top cell with existing technologies and at very little optimization in terms of bandgap widening and Fill Factor (FF) enhancement (Mailoa et al., 2015). With a reasonable estimate of achieving $20 \mathrm{mAcm}^{-2}$ and Voc of $1.1 \mathrm{~V}$ at the top Perovskite cell, a silicon cell generating $0.75 \mathrm{~V}$ Voc will lead to a FF of 0.8 and efficiency of $29.6 \%$ (Snaith, 2013). Tandem solar cells have attracted the attention of researchers around the world as it offers an alternative path towards higher efficiencies when compared to those obtained from single solar cell structures. For a good tandem solar cell structure, an optimized top and bottom cell structure must be used in order to achieve maximum conversion efficiency (Olopade et al., 2015).

\section{SYNTHETIC METHODS}

Perovskite solar cells can be manufactured with simpler wet chemistry techniques in a traditional laboratory environment, unlike silicon solar cells that need expensive, multi-step processes requiring an extreme temperature and vacuum controlled system. Perovskites can be created using a variety of solvent techniques and vapour deposition methods (Dawn, 2016). Approaches reported for the synthesis of Perovskite active layers are: one-step precursor solution deposition; two-step sequential deposition; dual-source vapour deposition; vapour assisted solution process; and sequential vapour deposition (Liu et al., 2013; Burschka et al., 2013; Hu et al., 2014). Categorically, we can put the synthesis methods of Perovskite under these broad heading: solvent techniques (solution processing); vapour assisted solution processing and vacuum deposition.

\section{PEROVSKITE FILM FORMATION}

Various processing techniques have been documented to fabricate hybrid Perovskite films. The major methods of fabricating Perovskite solar cells as suggested by Ezike et al. (2017) are Spin - coating, Vapour deposition and thermal evaporation methods. Spin-coating methods include one - step, two - step/ sequential deposition and vapour deposition method which include vapour - assisted deposition, and dual - source vapour deposition, and thermal evaporation technique (dual source approach) have been used to prepare $\mathrm{CH}_{3} \mathrm{NH}_{3} \mathrm{PbX}_{3}$ materials (Ezike et al., 2017).

It has also been suggested that the optoelectronic properties of Perovskite films are closely related to the 
processing conditions, such as the starting material ratio and the atmospheric conditions during film growth, which lead to a substantial difference in the film quality and device performance (Wang et al., 2014). Hybrid Perovskite materials form with crystallinity, even when processed at low temperatures, and the formation of the final Perovskite phase benefits from the relatively high reaction rates between the organic and inorganic species. These advantages substantially expand the choices of available processing methods such as thermal evaporation and solution processing, and facilitate the adoption of new and varied architecture (Song et al., 2015).

In solution processing of Perovskite film, a mixture of $\mathrm{MX}_{2}(\mathrm{M}=\mathrm{Pb}, \mathrm{Sn} ; \mathrm{X}=\mathrm{Cl}, \mathrm{Br}, \mathrm{I})$ and $\mathrm{AX}(\mathrm{A}=$ methylammonium, MA; Formamidinium, FA) is dissolved in an organic solvent and deposited directly to form a film and followed by thermal annealing to produce the final Perovskite phase (You et al.,2014).

In thermal evaporation synthesis of Perovskite film, a dual source is employed for $\mathrm{MX}_{2}$ and $\mathrm{AX}$ with different heat temperatures to form the Perovskite film (Liu et al.,2013). Both solution processing and thermal evaporation methods described above are one-step processing methods. In one -step method, both the organic and inorganic halides are stoichiometrically prepared in a common solution and are then spin coated into a thin film. In sequential deposition synthesis of Perovskite films, $\mathrm{MX}_{2}$ layer such as $\mathrm{PbI}_{2}$ and an $\mathrm{AX}$ such as Methylammonium iodide (MAI) are deposited sequentially followed by heat treatment to form the completed Perovskite film (Xiao et al., 2014). The deposition of the $\mathrm{MX}_{2}$ is done by spin-coating while AX can be introduced by spin-coating the $\mathrm{AX}$ solution on top of the $\mathrm{MX}_{2}$ layer or the $\mathrm{AX}$ solution can be immersed in $\mathrm{MX}_{2}$ layer to induce a solid-liquid reaction or by exposing the $\mathrm{MX}_{2}$ layer to $\mathrm{AX}$ vapour at elevated temperatures (Pang et al., 2014). Spin-coating deposition processes allow metal halide and organic halide to be dissolved in organic solvents which is followed by deposition on a substrate from which the formation of the Perovskite is achieved through annealing around $100^{\circ} \mathrm{C}$. This method is a low-cost approach but it wastes a lot of precursors.

Two-step sequentially deposition can be carried out in thermal evaporation, by sequential deposition the inorganic and organic components. Here, the $\mathrm{PbI}_{2}$ is first spin-casted followed by solution processing or vacuum assisted deposition of MAI (Hu et al., 2014). It is a heterophase reaction resulting in conversion to $\mathrm{MAPbI}_{3}$. A modification of two-step deposition method is the vapour assisted growth of MAI on the PbI film. Compact and uniform $\mathrm{PbI}_{2}$ film obtained by solution processing is exposed to MAI vapour under ambient conditions. In contrast to vapour depositing, this method does not require expensive vacuum equipment and environmental controls. Combining the advantages of solution processing and low temperature vapour deposition, the films grown are pinhole-free offering higher efficiencies (Hu et al., 2014; Xiao et al., 2014). In vapour deposition method, the substrate is exposed to one or more volatile precursors, which react with the substrate and/or decompose to produce the wanted deposit. It can be when the metal halide is deposited by spin -coating or other methods and volatile organic halide is deposited by ejecting it to give out vapour in the reaction chamber (Ezike et al., 2017). The vapour process is argued to be better than the solution process in planar heterojunction layout because the former produces a flat and even surface (Kesinro et al., 2017).

Dual source vapour deposition method involves simultaneous evaporation of organic and inorganic salts from respective sources at high vacuum. PCE of $\sim 12 \%$ was achieved using this method (Liu et al., 2013). Dual source of organic and inorganic halide ejects the vapours to the substrate exposed in the chamber. It is a low-cost method, uniform step coverage, fast deposition, low processing temperature and high throughput.

Thermal evaporation is widely used as a technique for the preparation of thin films for deposition of 
metals, alloys and many compounds. The requirement is to create vacuum environment where enough heat is given to the evaporants to attain the vapour pressure required for evaporation (Abbas et al., 2015).

\section{SYNTHESIS OF PEROVSKITE-SENSITIZED SOLAR CELLS}

A typical DSSC is a Mesoporous n-type Titania sensitized with a light absorbing dye in a redox active electrolyte. It was in the process of finding a more efficient light sensitizer for DSSCs that Miyasaka et al. reported the first Perovskite-sensitized solar cells, which they formed employing $\mathrm{CH}_{3} \mathrm{NH}_{3} \mathrm{PbI}_{3}$ and $\mathrm{CH}_{3} \mathrm{NH}_{3} \mathrm{PbBr}_{3}$ absorbers with an iodide triiodide redox couple (Kojima et al., 2006).

\section{SYNTHESIS OF MESOPOROUS TIO 2 STRUCTURES}

A typical fabrication procedure for Mesoporous scaffold-based Perovskite solar cells involves the use of FTO substrates with a compact $\mathrm{TiO}_{2}$ blocking layer and a Mesoporous oxide layer that have each undergone high temperature sintering steps $\left(500^{\circ} \mathrm{C}\right)$. In solution processing, Dawn, 2016 gave an elaborate explanation of the procedures as follows: the FTO substrates are cleaned in an ultrasonic bath with a combination of methanol and acetone and finally dried with Nitrogen gas. After the preparation of FTO substrates, the $0.15 \mathrm{M}$ and $0.3 \mathrm{M} \mathrm{TiO}_{\mathrm{x}}$ precursor solutions are prepared from titanium diiosopropoxide bis (acetyl acetone) $(0.0055 \mathrm{~mL}$ and $0.11 \mathrm{~mL})$ with 1-butanol $(1 \mathrm{~mL})$. The initial step is to spin-coat $0.15 \mathrm{M} \mathrm{TiO}_{\mathrm{x}}$ precursor solution on the FTO glass substrate at $3000 \mathrm{rpm}$ for 30 seconds, and annealed at $125^{\circ} \mathrm{C}$ for 5 minutes. This $0.30 \mathrm{M}$ solution process is performed twice, after which the FTO substrate is sintered at $5000^{\circ} \mathrm{C}$ for 30 minutes to form a compact $\mathrm{TiO}_{2}$ layer.

To prepare the Mesoporous $\mathrm{TiO}_{2}$ layer, a $\mathrm{TiO}_{2}$ paste is made using $\mathrm{TiO}_{2}$ powder $(100 \mathrm{mg})$ and polyethylene glycol $(10 \mathrm{mg})$ in ultrapure water $(0.5 \mathrm{~mL})$. This solution is then mixed with acetyl acetone $(10.0 \mu \mathrm{L})$ and triton X-100 (5 $\mu \mathrm{L})$ for 30 minutes and left for 12 hours. This helps in suppressing the formation of bubbles in the solution. The $\mathrm{TiO}_{2}$ paste obtained is coated on the substrate by spin-coating at 5000rpm for 30 seconds. The cells are annealed at $120^{\circ} \mathrm{C}$ for 5 minutes and at $500^{\circ} \mathrm{C}$ for 30 minutes. To syntheses methyl ammonium iodide $\left(\mathrm{CH}_{3} \mathrm{NH}_{3} \mathrm{I}\right), 23.2 \mathrm{~mL}$ of methylamine $\left(\mathrm{CH}_{3} \mathrm{NH}_{2}\right)$ is reacted with $25.0 \mathrm{~mL}$ of hydroiodic acid at $0^{\circ} \mathrm{C}$ for 2 hours with stirring. The precipitate is collected by removing the solvents at $50^{\circ} \mathrm{C}$ for 1 hour. The product obtained is redissolved and stirred in diethyl ether for 30 minutes to remove any impurities and dried using a rotary evaporator at $60^{\circ} \mathrm{C}$ for 3 hours. The $\mathrm{CH}_{3} \mathrm{NH}_{3} \mathrm{I}$ thus produced is finally dried in a vacuum.

To prepare Methylammonium lead iodide $\left(\mathrm{CH}_{3} \mathrm{NH}_{3} \mathrm{PbI}_{3}\right)$ with a Perovskite structure, a solution of $\mathrm{CH}_{3} \mathrm{NH} 3 \mathrm{I}(98.8 \mathrm{mg})$ and $\mathrm{PbI}_{2}(289.3 \mathrm{mg})$ at a mole ratio of $1: 1$ iny-butyroactone $(0.5 \mathrm{~mL})$ is mixed at $60^{\circ} \mathrm{C}$. The $\mathrm{CH}_{3} \mathrm{NH}_{3} \mathrm{PbI}_{3}$ solution is then introduced into the $\mathrm{TiO}_{2}$ Mesoporous using a spin-coating method and annealed at $100^{\circ} \mathrm{C}$ for 15 minutes. Next step is to prepare the Hole-transport layer (HTM) by spin-coating. A solution of spiroOMeTAD $(36.1 \mathrm{mg})$ in chlorobenzene $(0.5 \mathrm{~mL})$ is mixed with a solution of lithium bis (trifluoromethylsulfonyl) imide $(260 \mathrm{mg})$ in acetonitrile $(0.5 \mathrm{~mL})$ for 12 hours. This solution and 4-tert-butylpyridine $(4 \mu \mathrm{L})$ is then mixed with the Li-TFSL solution $(8.8 \mu \mathrm{L})$ for 30 minutes at $70^{\circ} \mathrm{C}$. All procedures are carried out in air. Finally, gold $\mathrm{Au}$ metal contacts is evaporated onto the sample as top electrodes. Figure 3 below shows the above detailed process. 


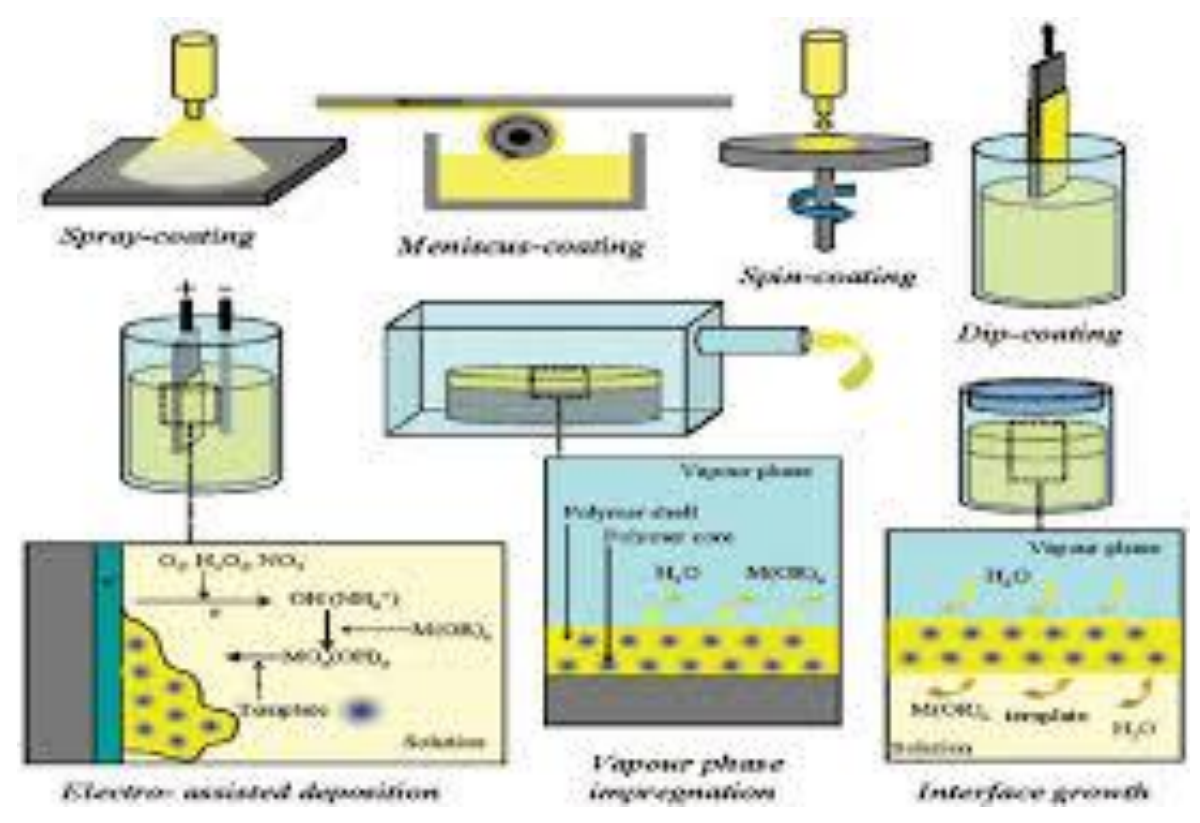

Figure 3: Synthesis of Mesoporous $\mathrm{TiO}_{2}$ Structures

Source: Luther and Ranjit (2014).

\section{SYNTHESIS OF PLANAR STRUCTURE}

As earlier stated, planar junction PSCs have a several hundred nanometer thick absorber layer which is sandwiched between ETL and HTL without a Mesoporous scaffold. This architecture offers the advantages of a simplified device configuration and fabrication procedure. These structures are mostly commonly illuminated from the $\mathrm{n}$ type side, resulting in the structure glass/TCO/ETL/Perovskite/ETL/metal (Jeng et al., 2013; Chiang et al., 2014).

The earliest attempts to fabricate planar Perovskite solar cells used single step deposition to deposit the Perovskite absorber layer. Compared to the Mesoporous scaffold, thermal evaporation can be more efficiently applied in a planar configuration, without worrying about the difficulty of Perovskite precursors penetrating into the Nanoporous scaffold. Bi et al., 2013 attempted by thermal co-evaporation of $\mathrm{CH}_{3} \mathrm{NH}_{3} \mathrm{I}$ and $\mathrm{PbCl}_{2}$ and deposited $\mathrm{CH}_{3} \mathrm{NH}_{3} \mathrm{PbI}_{3-\mathrm{x}} \mathrm{Cl}_{3}$ onto FTO with a thin $\mathrm{TiO}_{2}$ layer resulting in a PCE of $15.4 \%$ (Bi et al., 2013).

\section{SYNTHESIS OF MESO PSCS (MSSC) SUPERS STRUCTURED}

These devices are fabricated by spin-coating $\mathrm{CH}_{3} \mathrm{NH}_{3} \mathrm{PbI}_{2} \mathrm{Cl}$ mixed Perovskite with alumina layer in a photovoltaic cell. A Mesosuperstructure concept was evaluated using $\mathrm{ZrO}_{2}$ Mesoporous scaffold with $\mathrm{CH}_{3} \mathrm{NH}_{3} \mathrm{PbI}_{3}$ light harvester which exhibited significant photovoltaic activity Voc of approximately $900 \mathrm{mV}$ through lower than titania (Kim et al., 2013).

\section{SYNTHESIS OF HYBRID PEROVSKITE SOLAR CELLS}

This is a device structure based on $\mathrm{TiO}_{2} / \mathrm{CH}_{3} \mathrm{NH}_{3} \mathrm{PbI}_{3-\mathrm{x}} \mathrm{Cl}_{3}$ / P3HT, with the incorporation of self-assembled monolayer (e.g. C60). Here, the ITO substrate is treated with the C60 self-assembled monolayer (Jeng et al., 2013). The concept of hybrid planar heterojunction cell incorporating $285 \mathrm{~nm}$ thick layer of $\mathrm{CH}_{3} \mathrm{NH}_{3} \mathrm{PbI}_{3}$ was investigated by Abrusci et al., 2013. Active layer was sandwiched between hole-transporting poly ( $\mathrm{N}, \mathrm{N}^{1}$ - bis(4butylphenyl)-N, $\mathrm{N}^{1}$-bis (phenyl)-benzidine) (poly-TPD) layer (10nm) and electron accepting PCBM layer (10nm). 
The charge collecting layers were solution-processed in spin-coated chlorobenzene while the active layer was vacuum-deposited by heating reagents $\mathrm{CH}_{3} \mathrm{NH}_{3} \mathrm{I}$ to $70^{\circ} \mathrm{C}$ and $\mathrm{PbI}_{3}$ to $250^{\circ} \mathrm{C}$.

\section{SYNTHESIS OF FLEXIBLE PEROVSKITE SOLAR CELLS}

These PSCs consist of fabricating the cells on flexible substrates. Malinkiewicz et al., 2014 investigated this using both regular and inverted device architecture on an ITO coated PET substrate. $\mathrm{A} \mathrm{CH}_{3} \mathrm{NH}_{3} \mathrm{PbI}_{3-\mathrm{x}} \mathrm{Cl}_{\mathrm{x}}$ active layer with PEDOT: PSS and PCBM as hole-transporting and electronic selective contacts were used. A PCE of $6.4 \%$ was achieved (Malinkiewicz et al., 2014). A higher PCE of 10.2\% was achieved using device structure of ITO/ZnO (25nm)/ $/ \mathrm{CH}_{3} \mathrm{NH}_{3} \mathrm{PbI}_{3} /$ Spiro-OMeTAD/AG, fabricated using low temperature solution processing methods (Docampo et al., 2013).

\section{PEROVSKITE PHASE FORMATION}

Depending on the relative sizes of the cation and the octahedron in a Perovskite structure, the Perovskite phase can be three dimensional (3D), two-dimensional (2D) or even one-dimensional (1D) in crystal structure (Stoumpos et al., 2013).

Focusing on 3D organo-metal halide Perovskite phases, it is worth noting that the formation of Perovskite structures usually follows the overall reaction formula $\mathrm{AX}+\mathrm{BX}_{2} \rightarrow \mathrm{ABX}_{3}$. Using this reaction as a typical example, it has been observed that the reaction kinetics of Perovskite phase formation are very fast (Liu and Kelly, 2013). During the transformation into the Perovskite lattice, spaces are formed between the layered $\mathrm{PbI}_{6}$ octahedral that share facets with $\mathrm{PbI}_{2}$ to create $\mathrm{PbI}_{6}$ octahedral that share only vertices in $\mathrm{MAPbI}_{3}$. Solution of $\mathrm{PbI}_{2}$ is another important parameter that affects the intermediate reaction stage. Since it has been demonstrated that the soft $\mathrm{Pb}$ can easily coordinate with a variety of small molecules such as ethanolamine or dimethyl sulfoxide (DMSO), after which the original facet-sharing $\left(\mathrm{PbI}_{6}\right)$ octahedral are partially disintegrated and small ligands are inserted, it is therefore logical to conclude that during the dissolution of $\mathrm{PbI}_{2}$, solvent molecules partially replace iodine to ligate with lead, thus facilitating the subsequent reaction forming the Perovskite phase.

Besides the kinetics of phase formation, another issue is the formation of mixed-cation, mixed group IV metal, and mixed-halide Perovskite phases, allowing for the fine tuning of the optical and electronic properties of the final material (Song et al., 2015). A Perovskite phase with mixed-group IV metals has recently been synthesized using MAI and a mixture of $\mathrm{PbI}_{2}$ and $\mathrm{SnI}_{2}$ (Hao et al., 2014).

$\mathrm{MAPbX}_{3}$-based Perovskite have been found to exhibit multiple phases as a function of temperature and composition. These different phases possess dramatically different electrical/optical properties as well as stability. Stoumpos et al., showed that $\mathrm{MAPbI}_{3}$ exhibited an X-phase, $\delta$-phase and $\gamma$-phase with transition temperature of $400^{\circ} \mathrm{K}, 333^{\circ} \mathrm{K}$, and $180^{\circ} \mathrm{K}$ respectively (Stoumpos et al., 2013). Phase transformation can also occur in mixed halide systems. A mixed halide $\mathrm{MAPbI}_{3-\mathrm{x}} \mathrm{Br}_{\mathrm{x}}(0 \leq \mathrm{X} \leq 3)$ was used for band-gap tuning and it was observed that the crystal structure transformed from the tetragonal phase to a cubic phase when the percentage of Br present passed a threshold of approximately $\mathbf{X}$ approx. $\mathbf{0 . 5}$ (Noh et al.,2013). This phase transition has been presumed to explain the improved stability of $\mathrm{MAPbI}_{3-\mathrm{x}} \mathrm{Br}_{\mathrm{x}}$ materials in the air and humidity test, making it an interesting addition to our understanding of the specifics of the Perovskite lattice. 


\section{PEROVSKITE FILM QUALITY}

Based on various processing approaches, Perovskite materials exhibit a wide range of film properties like grain size, morphology, crystallinity, surface coverage, etc. Several works have also shown that Perovskite films exhibit composition/structure dependent properties (Song et al., 2015). Therefore, since it is essential to achieve fine control over the reaction between the inorganic and organic species so as to produce Perovskites within the required properties, various process parameters have to be incorporated. Paramount among these are: stoichiometry, thermal treatment, solvent engineering, additives and environmental control.

The stoichiometry, particularly the ratio of the organic to inorganic component, largely affects the resulting $\mathrm{MAPbI}_{3-\mathrm{x}} \mathrm{Cl}_{\mathrm{x}}$ film quality in terms of film conformity and carrier behaviour. Generally, a solution of $\mathrm{PbX}_{2}$ and MAX with a stoichiometry of 1:1 is used as the precursor to form a pure Perovskite phase (Song et al., 2015). Further studies on film formation based on stoichiometry effects have also been conducted, in terms of the phase, the underlying reaction, and the possible byproducts. Details about this can be found in the works of Lee et al. (Lee et al., 2012).

Thermal annealing is an essential step to initiate or accelerate the reaction between the molecules, as well as the film formation. A delicate control of heat treatment is needed due to the fast reaction rate between the organic-inorganic component and their various phase in the low temperature of hybrid Perovskite range materials. Eperon et al., investigated the properties of mixed halide Perovskite $\mathrm{MAPbI}_{3-\mathrm{x}} \mathrm{Cl}_{\mathrm{x}}$ planar films based on one-step solution processing at different annealing temperatures (Eperon et al., 2013). The authors observed that the higher the annealing temperature, the lower the film surface coverage. Liang et al. added 1\% of 1, 8, diiodooctane (Dio) into a Perovskite precursor solution and demonstrated an increase in device performance in contrast to devices based on precursors without additives (Liang et al., 2014). The films exhibited improved surface coverage and crystallinity as observed using SEM and XRD, respectively. This result showed that the inclusion of small amounts of chemical additives in Perovskite precursor solutions can provide advantages in terms of crystallinity, film coverage, and the resulting device performance. It also showed that the film growth can be effectively controlled.

Generally, Perovskite films are deposited and annealed in nitrogen or dry air glove boxes with $\mathrm{H}_{2} \mathrm{O}$ levels less than 5ppm, as the presence of moisture was deduced to deteriorate the Perovskite film. However, Zhou et al. found that Perovskite films annealed in a mild moisture environment of approximately $30 \%$ humidity. And could improve film properties significantly (Zhou et al., 2014). The speculation is that the moisture could enhance film formation by partially dissolving the reaction species and accelerating mass transport within the film. It could also possibly promote the movement of organic species and accelerate the grain growth resulting in less pinholes in the films. This result indicates that a controlled atmosphere during the film formation will result in high performance Perovskite devices. The quality of hybrid Perovskite films can be determined by the critical role solvents play in all kind of solution processes. The selection of solvents with sufficient solubility for organic and inorganic precursor components is limited due to their distinct nature (Song et al., 2015). Currently, DMF, DMSO, GBL and their mixtures are majorly used. These solvents have been shown to improve the film optoelectronic properties and device performance (Kim et al, 2012; Zhan et al; 2014). Kim et al; reported that mixed solvents have improved the morphology of the Perovskite film (Kim et al; 2014). Therefore, the solvents either from the precursor solution or induced during the processing, substantially influencing the molecule/species interaction within the system, and the subsequent film quality. 


\section{CHALLENGES}

\section{STABILITY ISSUES OF PEROVSKITE}

Stability and efficiency are two factors important for the commercial application of Perovskite solar cells.

For their commercial viability, it is imperative that studies be undertaken on issues of stability and reproducibity to enhance the lifetime of these devices (Muhammad et. al., 2015). Degradation in Perovskite solar cells is a synergetic effect of moisture, ultraviolet light, temperature, and the effects of hysteresis and ion migration.

\section{MOISTURE}

Niu et. al. proposed a sequence of chemical reactions considered responsible for the degradation of $\mathrm{CH}_{3} \mathrm{NH}_{3} \mathrm{PbI}_{3}$ in the presence of moisture (Niu et al., 2014). By comparing XRD patterns before and after exposure to water, they were able to propose the following series of reactions (equations 4.1 to 4.4 ) for the moisture catalyzed decomposition of the Perovskite layer as follows:

$$
\begin{aligned}
& \mathrm{CH}_{3} \mathrm{NH}_{3} \mathrm{PbI}_{3} \leftarrow \mathrm{H}_{2} \mathrm{O} \rightarrow \mathrm{CH}_{3} \mathrm{NH}_{3} \mathrm{I}_{(\mathrm{aq})}+\mathrm{PbI}_{2(\mathrm{~S})} \\
& \mathrm{CH}_{3} \mathrm{NH}_{3} \mathrm{I}_{(\mathrm{aq})} \leftrightarrow \mathrm{CH}_{3} \mathrm{NH}_{2(\mathrm{aq})}+\mathrm{HI}_{(\mathrm{aq})} \\
& 4 \mathrm{HI}_{(\mathrm{aq})}+\mathrm{O}_{2} \leftrightarrow 2 \mathrm{I}_{2(\mathrm{~s})}+2 \mathrm{H}_{2} \mathrm{O} \\
& 2 \mathrm{HI}_{(\mathrm{aq})} \leftarrow \mathrm{h}_{\mathrm{V}} \rightarrow \mathrm{H}_{2} \uparrow+\mathrm{I}_{2(\mathrm{~S})}
\end{aligned}
$$

Multiple reports have suggested that water is the catalyst required for the irreversible degradation of the Perovskite material (Wang et. al., 2016). Figure 4 below shows the proposed decomposition pathway of $\mathrm{CH}_{3} \mathrm{NH}_{3} \mathrm{PbI}_{3}$ in the presence of a water molecule.
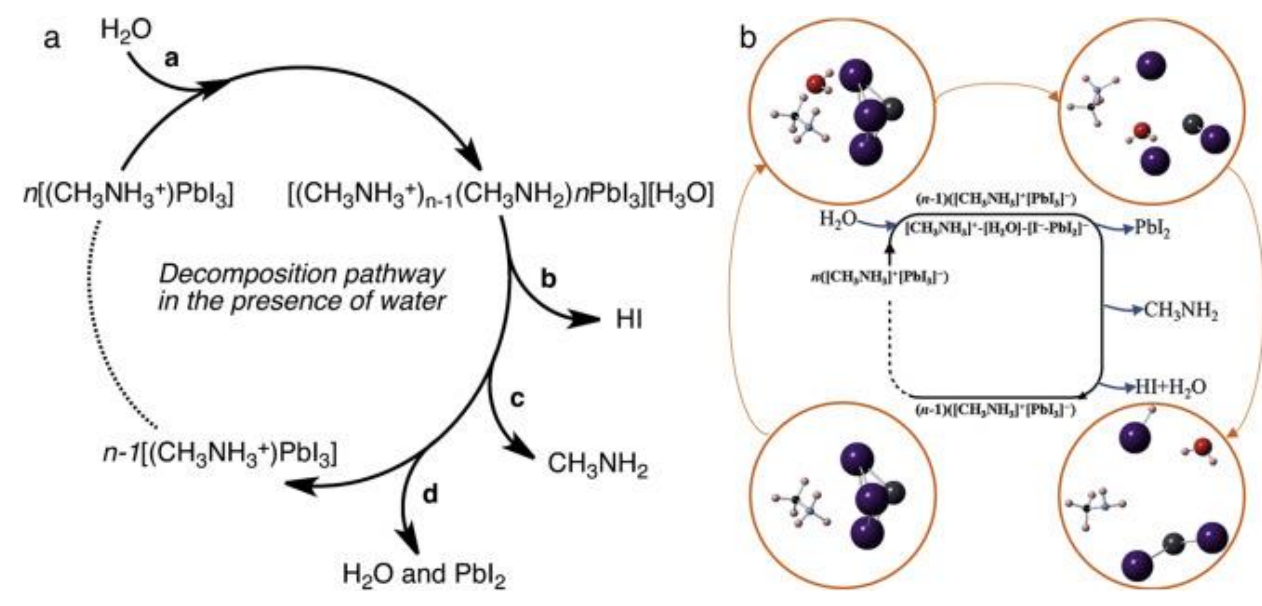

Figure 4: Proposed Decomposition Pathway of $\mathrm{CH}_{3} \mathrm{NH}_{3} \mathrm{PbI}_{3}$ in the Presence of a Water Molecule

Source: Jianqing et al. (2017).

The irreversible degradation of the Perovskite layer is a challenge facing the lifetime of a photovoltaic cell. However, the challenge is compounded by the nature of the by-products. One of the by-products of this reaction 
is $\mathrm{PbI}_{2}$, (Eqn 1a) which itself is soluble in water (Yang et al., 2015). The decomposition of $\mathrm{PbI}_{2}$ in installed modules could cause significant eco-toxicological problems in the field.

In contrary to the findings of Niu et al. In Situ grazing incidence x-ray diffraction (GiXRD) measurements provided another insight into the decomposition reaction occurring in the $\mathrm{CH}_{3} \mathrm{NH}_{3} \mathrm{PbI}_{3}$ film (Yang et al., 2015). The authors discovered a new crystalline phase which they speculated as a hydrated compound $\left[\left(\mathrm{CH}_{3} \mathrm{NH}_{3}\right)_{4} \mathrm{PbI}_{6}\right.$ $\cdot \mathrm{H}_{2} \mathrm{O}$ ] when they exposed the Perovskite film to $80 \%$ relative humidity $(\mathrm{RH})$ for 2.5 hours. The formation of this

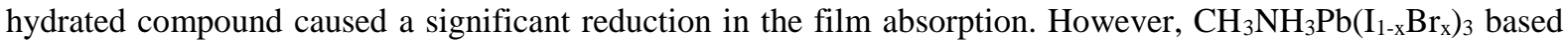
absorbers retained good PCE on exposure to humidity of $55 \%$ for 20 days (Noh et al., 2013).

\section{ULTRAVIOLET RADIATIONS}

Illuminations with UV light can cause degradation in Perovskite solar cells. UV sensitivity is attributed to use of $\mathrm{TiO}_{2}$ as photo anode in PSC. Proposed degradation mechanism for $\mathrm{CH}_{3} \mathrm{NH}_{3} \mathrm{PbI}_{3}$ under UV illumination was given by (Ito et al., 2014) and equations 2 a to 2 b shows:

$$
2 \mathrm{I}^{-} \leftrightarrow \mathrm{I}_{2}+2 \mathrm{e}^{-}
$$

At the interface between $\mathrm{TiO}_{2}$ and $\mathrm{CH}_{3} \mathrm{NH}_{3} \mathrm{PbI}_{3}$, we have:

$$
\begin{gathered}
3 \mathrm{CH}_{3} \mathrm{NH}_{3}{ }^{+} \leftrightarrow 3 \mathrm{CH}_{3} \mathrm{NH}_{2} \uparrow+3 \mathrm{H}^{+} \\
\mathrm{I}^{-}+\mathrm{I}_{2}+3 \mathrm{H}^{+}+2 \mathrm{e}^{-} \leftrightarrow 3 \mathrm{HI} \uparrow
\end{gathered}
$$

Leijtens et al. showed that for Perovskite solar cells, this $\mathrm{TiO}_{2}$ layer is susceptible to UV-induced degradation (Leijtens et al., 2013). This was investigated by measuring a 5h efficiency decay curve, measured under 1 sun AM 1.5G illumination for devices with and without encapsulation and a UV filter. The results showed that, un-intuitively, the encapsulated device degrades more rapidly than the non-encapsulated device. These authors after several measurements to confirm the UV light degradation of PSCs proposed three methods to circumvent the problem viz: pacifying the trap states; avoiding UV light from reaching the $\mathrm{TiO}_{2}$ layer and or; replacing the $\mathrm{TiO}_{2}$ scaffold with another material.

The use of $\mathrm{Sb}_{2} \mathrm{~S}_{3}$ blocking layer was investigated to reduce UV induced degradation by Ito et al. The technique involves depositing a $\mathrm{Sb}_{2} \mathrm{~S}_{3}$ layer at the $\mathrm{TiO}_{2} / \mathrm{CH}_{3} \mathrm{NH}_{3} \mathrm{PbI}_{3}$ interface (Ito et. al., 2014). The inclusion of this buffer layer improved the stability greatly. Without $\mathrm{Sb}_{2} \mathrm{~S}_{3}$, the $\mathrm{CH}_{3} \mathrm{NH}_{3} \mathrm{PbI}_{3}$ decomposed to $\mathrm{PbI}_{2}$ which correlates with the colour change to yellow. Whereas, $\mathrm{CH}_{3} \mathrm{NH}_{3} \mathrm{PbI}_{3}$ maintains its crystalline structure with $\mathrm{Sb}_{2} \mathrm{~S}_{3}$ buffer layer. The author reasoned that what happens when the $\mathrm{Sb}_{2} \mathrm{~S}_{3}$ layer inserted at the interface blocks the UV induced photo catalysis in $\mathrm{TiO}_{2}$ may be passivation.

\section{TEMPERATURE}

Thermal stability studies are very important as exposure to elevated temperatures causes degradation of the Perovskite layer. This is so because temperatures are expected to be over the phase transition temperature of $\mathrm{CH}_{3} \mathrm{NH}_{3} \mathrm{PbI}_{3}$; changing from tetragonal to cubic structure at $56 \%$. Phillippe et al. investigated the influence of elevated temperatures on both $\mathrm{CH}_{3} \mathrm{NH}_{3} \mathrm{PbI}_{3}$ and $\mathrm{CH}_{3} \mathrm{NH}_{3} \mathrm{PbI}_{3-\mathrm{x}}$ films (Phillippe et al., 2015). Here, the authors heated the films in an analysis chamber under an ultra-high vacuum. Removing the presence of water and air allowed for the isolation of the effect of temperature on the film degradation. The films were characterized using the $\mathrm{I} / \mathrm{Pb}$ and $\mathrm{N} / \mathrm{Pb}$ ratios, extracted from hard $\mathrm{x}$-ray photoelectron spectroscopy (PES). A reduction of these ratios indicates the conversion of the Perovskite into $\mathrm{PbI}_{2}$. Heating at $100^{\circ} \mathrm{c}$ for 20 minutes led to a significant reduction of both ratios. Further heating at $200^{\circ} \mathrm{c}$ caused both ratios to drop to a minimum, 2 and 0 , respectively. This is 
indicative of a film consisting of $100 \% \mathrm{PbI}_{2}$. The author suggested the following reaction for the temperature induced decomposition as shown in equation 3 below:

$$
\mathrm{CH}_{3} \mathrm{NH}_{3} \mathrm{PbI}_{3} \rightarrow \mathrm{PbI}_{2}+\mathrm{CH}_{2} \mathrm{NH}_{2} \uparrow+\mathrm{HI} \uparrow
$$

Characterization results clearly shows the instability of the Perovskite material under elevated temperatures.

Thermal decomposition of Perovskite layer has also been reported to depend on the underlying layer (Yang et al., 2015). Although initial reports used a $\mathrm{TiO}_{2}$ scaffold, the requirement to reduce the fabrication temperature has been to replace $\mathrm{TiO}_{2}$ with $\mathrm{ZnO}$. These authors also reported that the $\mathrm{ZnO} / \mathrm{CH}_{3} \mathrm{NH}_{3} \mathrm{PbI}_{3}$ interface appears to accelerate the thermal decomposition of the Perovskite layer. The film is less thermally stable, when compared to $\mathrm{TiO}_{2}$. Yang et al. used in situ absorption measurements to uncover the mechanism causing this instability (Yang et al., 2015).

\section{STABILITY OF THE ELECTRON TRANSPORT LAYER (ETL)}

Mesoporous Perovskite solar cells require an electron transport layer (ETL) and most commonly used is $\mathrm{TiO}_{2}$. Pathak et al. reported that non-stoichiometry defects such as oxygen vacancies and titanium interstitials can form in this layer (Pathak et al., 2014). These defects cause deep sub-band gap trap states, which reduce solar cell performance. Oxygen is required to passivate these traps; however, other layers in the device may require encapsulation to prevent moisture ingress. To solve this problem, Pathak et al. attempted aluminium-doping using $\mathrm{TiO}_{2}$. The $\mathrm{TiO}_{2}$ was doped using a sol-gel deposition process with an Al containing precursor. Low doping levels led to an increase in conductivity in the $\mathrm{TiO}_{2}$ layer. PDS measurements showed that these low doping levels reduced the number of trap states while the Aluminium served to passivate the non-stoichiometry defects increasing the device stability and performance. Song et al. have also shown this by fabricating planar Perovskite solar cell replacing $\mathrm{TiO}_{2}$ with $\mathrm{SnO}_{2}$ as the electron selective contact which gave rise to a champion cell efficiency of $13 \%$ (Song et al., 2015). Besides $\mathrm{TiO}_{2}, \mathrm{PCBM}$ has also been used as a transporting layer. Just as $\mathrm{TiO}_{2}$ layer is sensitive to ultraviolet light, PCBM is not stable in air (Song et al; 2015).

\section{STABILITY OF HOLE TRANSPORT LAYER (HTL)}

Spirobifluorene (spiro-OMeTAD) and poly (triarlyamine) PTAA are the most studied Hole transporting layer (HTL). The use of spiro-OMeTAD requires an addictive, e.g., 4-tert-butylpyridine (tBP), which can react with the Perovskite materials causing instability. Other HTLs that have been used include PEDOT: PSS and P3HT (poly (3-hexylthiophene)). The acidic nature of PEDOT: PSS also becomes a concern for the long-term stability of solar cells (Song et al., 2015). Yang et al. studied the ability for the hole transport layer to protect the underlying Perovskite film from moisture induced degradation (Yang et. al; 2015). Three HTLs were investigated viz; spiroOMeTAD, PTAA [poly (bis (4-phenyl) (2, 4, 6-trimethylphenyl)] and P3HT. Both PTAA and P3HT caused a reduction in the degradation rate under the investigated relative humidities. P3HT served to reduce the degradation rate by a factor of 6 while spiro-OMeTAD layer caused an acceleration of the Perovskite decomposition. The difference in their degradation rates was explained by the discrepancies in the mechanical toughness of the layer. SEM images showed that spiro-OMeTAD layer underwent significant cracking, hence increased decomposition rate, while other HTL layers formed a conformal barrier layer which reduced the ingress of moisture to the Perovskite film.

In 2014, Habisrentingeer et al. investigated the influence of the HTL on the thermal and 
moisture-induced degradation of Perovskite solar cells (Habisrentinger et al; 2014). Spiro-OMeTAD, P3HT and PTAA HTLs yielded the highest efficiency results. One advantage of using P3HT is that the cost is reduced, due to both reduced material cost, and reduced layer thickness. The authors suggested that P3HT could be 10 times cheaper than spiro-OMeTAD (Zhang et al., 2015). Yan et al. replaced PEDOT: PSS with a thin polythiophene (PT) film, deposited by electrochemical polymerization (Yan et al., 2015). The optimized efficiency for $\mathrm{PT} / \mathrm{CH}_{3} \mathrm{NH}_{3} \mathrm{PbI}_{3}$ devices was higher than the reference devices using PEDOT: PSS. They proposed that the electrochemical polymerization employed to form the PT film is compatible with large-scale production. HTLs commonly used are organic materials. Kim et al. incorporated an inorganic $\mathrm{HTL}, \mathrm{NiO}_{\mathrm{x}}$ (Kim et al; 2015). The authors observed that such inorganic oxide films display better environmental stability than their organic counterparts. However, organic HTLs gave higher device efficiency.

\section{STABILITY OF PSCS VIA BUFFER LAYER}

The addition of buffer layer was shown to improve the device efficiency and stability. (Guarnera et al., 2015). They did this by incorporating $\mathrm{Al}_{2} \mathrm{O}_{3}$ Nano particles between the Perovskite absorber and the HTL. This improvement was due to an improved fill factor (FF). The buffer layer allows for a reduction in the thickness of the HTM layer causing a reduction in series resistance, thus improving fill factor. The author later propose that the degradation was not induced by moisture or UV radiation, but by the migration of metal from the top contact to the Perovskite layer. The buffer layer stopped the movement of metal to the Perovskite absorber which would otherwise cause shunt pathways (Guarnera et al., 2015).

\section{STABILITY OF THE ELECTRODE}

High efficiency PSCs make use of Gold ( $\mathrm{Au}$ ) as the electrode material but this material is prohibitively expensive (Sheikh et al., 2015). Michui et al. demonstrated in polymer solar cell modules how silver (Ag) paste can be alternative choice to $\mathrm{Au}$ (Machui et al., 2014). But an issue which provides a barrier to the use of Ag as electrode for PSCs was uncovered by Kato et al. (Kato et al., 2015). They found that PSC, using Ag as the electrode display worse environmental stability than those using $\mathrm{Au}$ electrode. Further investigation revealed that exposure to humidity ( $\mathrm{RH} \sim 50 \%$ ) caused a formation of AgI, making the electrode color to change from a reflective metal to a yellowish color. This however results to reduced efficiency. This environmental instability of the electrode is ultimately caused by the nature of the HTL, indicative of the inter-related nature of the degradation pathways within all layers in a PSC. Mei et al. fabricated a hole-conductor-free PSC with a printed carbon electrode (Mei et al., 2014) and the device displayed excellent stability. This was as a result of the presence of the thick carbon layer providing excellent protection and the stability also enhanced with the elimination of the hole transport medium. They concluded that though the stability is impressive, the device architecture contains layers processed at elevated temperatures $\left(400^{\circ} \mathrm{c}\right)$ which does not align with the desire of mass production.

Multiple novel applications of carbon electrodes have recently been reported (Li et al., 2015). These were archived by fabricating a flexible, fibre, supported PSC using nanotubes (CNT) fibres via a solution coating technique. They laminated a CNT network onto $\mathrm{CH}_{3} \mathrm{NH}_{3} \mathrm{PbI}_{3}$ removing the need for the HTL and metal electrode ( $\mathrm{Li}$ et al., 2014).

\section{HYSTERESIS EFFECTS}

The origin of hysteresis and its mechanism is a highly debated topic and has become an area of intense research. Understanding the ferroelectric behaviour of Perovskite solar cell materials may be critical in increasing its 
efficiency and stability. Ferro electricity may affect the photo excited electron hole pairing and separation (Liu $e t$ al., 2015). This behaviour of PSC material came under focus on the report of the hysteresis in current voltage scans, dependent on the scan rate and direction, light soaking history and contact material and interfaces (Unger et al., 2017). Recent reports on hysteresis have attributed the following to its causes: grain boundaries and size; charge trapping at the interface; ion migration within the crystal structure of Perovskites; defects states and surface imperfections of Perovskites (Stephan et al., 2015). Though the frontiers of understanding the intricacies causing hysteresis are evolving, its impact on operating stability of the device remains quite unclear (Wang et al., 2016). Snaith et al. have proposed capacitive effects, ferroelectric behaviour of absorber, and defect densities to be the sources of hysteresis behaviour (Snaith et al., 2014).

In organic-inorganic halide Perovskites, grain boundaries and imperfection on its surface may introduce localized states, which will serve as trap centres for photogenerated carriers. Because of its susceptibility to defect formation arising from low thermal stability of these PSC materials, these trap centres could induce a field across that can counteract with the overall photo voltage of the device. Hence, hindering its efficiency (Shao et al., 2014). Reports have shown $\mathrm{C}_{60}$ /fullerene passivation eliminates this kind of photocurrent hysteresis (Xu et al., 2015; Shao et al., 2014). The fullerene is found to interact with halide rich defective regions at the grain boundaries; leading to the passivation of localized trap states. Baena et al. reported a reduction in hysteresis by replacing $\mathrm{TiO}_{2}$ with $\mathrm{SnO}_{2}$ as the electron transport layer (ETL) (Baena et al., 2015). A $15 \mathrm{~nm} \mathrm{SnO}$ layer was deposited by low temperature atomic layer deposition (ALD). Planar Perovskite devices with $\mathrm{SnO}_{2}$ ETL thereby achieved efficiencies greater than $18 \%$. This reduction in hysteresis the authors attributed to a more favourable band alignment at the $\mathrm{SnO}_{2} /$ Perovskite interface.

\section{ION MIGRATION EFFECTS ON THE STABILITY OF PSCS}

The process of ion migration within the crystal structure of Perovskite is another issue that could potentially have an impact on device stability (Eames et al., 2015). Ion migration is sought to be a major reason for hysteresis observed in PSCs (Pellet et al., 2014). The diffusion of intrinsic ionic defects in organic-inorganic halide Perovskites has implications in terms of their long-term stability and performance efficiency. However, recent studies have revealed that the migration iodide ion vacancies under the influence of either electric field or light illumination could alter the collection of efficiency of the photogenerated carriers, causing hysteresis in PSCs (Zhao et al., 2015). Eames et al. also reported that the ionic conductivity in the PSCs depend on the intrinsic iodide ion vacancies, which is found to be dependent on the synthesis conditions and thermal processing techniques (Eames et al., 2015).

Tress et al. also reported that hysteresis was found to increase with aging of the device (Tress et al, 2015). The authors gave several reasons behind this anomalous behaviour to include: degradation of $\mathrm{CH}_{3} \mathrm{NH}_{3} \mathrm{I}$ and the formation of $\mathrm{PbI}_{2}$; and mobile iodide vacancies. Eames et al. concluded their work by portraying a picture of hybrid halide Perovskite to look like a mixed ionic-electronic conductor and this behaviour is expected to have major repercussions for unravelling the degradation pathways and for the design of future device architectures (Eames et al., 2015). 


\section{OVERCOMING THESE CHALLENGES}

\section{ATTEMPTS TO IMPROVE INTRINSIC STABILITY OF PSCS AND ITS GROWTH}

Variations on the most commonly used Perovskite material $\left(\mathrm{CH}_{3} \mathrm{NH}_{3} \mathrm{PbI}_{3}\right)$ structure may lead to improved environmental stability. Noh et al. tuned the stoichiometry of $\mathrm{CH}_{3} \mathrm{NH}_{3} \mathrm{~Pb}\left(\mathrm{I}_{1-\mathrm{x}} \mathrm{Br}_{\mathrm{x}}\right)_{3}$ of Perovskites by substituting I ions with Br ions (Noh et al., 2013). The author concluded that the stability of PSCs devices incorporating Br was found to be significantly improved. This improvement they attributed to a reduced lattice constant and a transition from tetragonal to cubic phase. The desire for non-toxic, solution processable solar cells has led a few researchers to consider alternatives to lead $(\mathrm{Pb})$ within the Perovskite structure (Wang et al., 2016). The most appropriate element to replace $\mathrm{Pb}$ is tin ( $\mathrm{Sn})$, as it is also a group 14 metal having four electrons in its outer shell. Noel et al. formed a device by spin-coating $\mathrm{CH}_{3} \mathrm{NH}_{3} \mathrm{SnI}_{3}$ on $\mathrm{TiO}_{2}$. The authors observed a decolouration/degradation of both the non-encapsulated and encapsulated devices they tested (Noel et al., 2014). Hao et al. also reported PSCs incorporating Sn halides and stability investigation was formed by encapsulating the device with surlyn films. They concluded that advances in encapsulation techniques are paramount if this material is to be suitable for future applications (Hao et al., 2014).

Espinosa et al. reported an initial life cycle assessment (LCA) and environmental impact analysis (EIA) for PSCs and concluded that the component contributing the most to environmental impact was the Perovskite layer, however, the $\mathrm{PbCl}_{2}$ contributed very little to this. The problem they said lay largely with MAI (Espinosa et al., 2014).

Smith et al. decided to investigate a two-dimensional (2D) layered Perovskite structure with the aim of improving the device stability (Smith et al, 2014). They reported better efficiencies with the use of the 2D layered synthesized Perovskite material as the absorber in PSC devices. The layered Perovskite also did not decompose after samples were exposed to RH of $52 \%$ in 46 days.

Ternary halide $\mathrm{Cs}_{3} \mathrm{Sb}_{2} \mathrm{I}_{9}$ was also investigated (Saparov et al., 2015). The lead-free material does not consist of a hydrophobic layer to protect the film. The authors recorded an enhanced stability which they attributed to the inorganic crystal structure or film grain size. $\mathrm{MAPbI}_{3}$ band gap value is $1.55 \mathrm{eV}$. This reported a higher value than the ideal value for a simple junction solar cell. By replacing the organic cation, it is possible to tune the band gap (Eperon et al., 2014). Eperon et al. showed that replacing the MAI cation with the larger FAI results in a reduction of the band gap to $1.48 \mathrm{eV}$. The narrower band gap allows FAI-based Perovskites to generate photocurrent over a larger spectral region, resulting in an increase in $\mathrm{J}_{\mathrm{sc}}$ (shunt current density). Additionally, the author also showed that FAI Perovskite exhibit improved charge transport characteristics compared to MAI Perovskite, allowing for easy integration into planar geometry devices. When exposed to temperatures of about $150^{\circ} \mathrm{C}$ in air, the FAI Perovskite films were stable. The authors then suggested that just unlike MAI, FAI films did not undergo discolouration. Further studies done by Lee et al. later showed that this stability was related to the crystal structure (Lee et al., 2014). Stoumpos et al. carried out Differential Scanning Calorimetry (DSC) measurements and found that FAI does not undergo a phase transition within the temperature range of 25 to $125^{\circ} \mathrm{C}$. This is unlike $\mathrm{MAPbI}_{3}$, which was shown to undergo a structural phase change at approximately $55^{\circ} \mathrm{C}$ (Stoumpos et al., 2013).

Li et al. in 2015 employed chemical Engineering to alter the stability of the commonly used $\mathrm{CH}_{3} \mathrm{NH}_{3} \mathrm{PbI}_{3}$. They achieved this by incorporating an addictive (butylphosphonic acid 4-ammonium chloride (4-ABPACl)) into a one-step spin coating method to modify the $\mathrm{CH}_{3} \mathrm{NH}_{3} \mathrm{PbI}_{3}$ surface (Li et al., 2015). XRD and TEM revealed that 
these additive molecules bond to the surface of $\mathrm{CH}_{3} \mathrm{NH}_{3} \mathrm{PbI}_{3}$, rather than becoming integrated into the Perovskite crystal structure. This has the effect of cross-linking adjacent Perovskite grains leading to the formation of a smoother capping layer, with improved infiltration into the underlying $\mathrm{TiO}_{2}$. Devices fabricated using the 4ABPACl cross-linked Perovskite film achieved efficiencies higher than $16 \%$.

$\mathrm{Xu}$ et al. (2016) reported a new approach to obtain a high quality $\mathrm{MAPbI}_{3-\mathrm{x}} \mathrm{Cl}_{\mathrm{x}}$ Perovskite layer, by pumping away the solvent of the precursor film before annealing to decrease the influence of solvent evaporation rate on the growth of $\mathrm{MAPbI}_{3-\mathrm{x}} \mathrm{Cl}_{\mathrm{x}}$ Perovskite film. This approach was proved to be effective as a compact and uniform Perovskite film with stronger absorption, fewer crystal defects, and smaller charge transfer resistance was formed. Devices based on this high-quality Perovskite film showed enhanced performance compared with the reference device. The averaged efficiency increased from 10.61 to $12.56 \%$ and a champion PCE of $14.0 \%$ was achieved.

Figure 5 below summarizes the growth of PSC since 2009 to 2016, while Figure 6 shows the reported efficiency of PSCs between the same period.

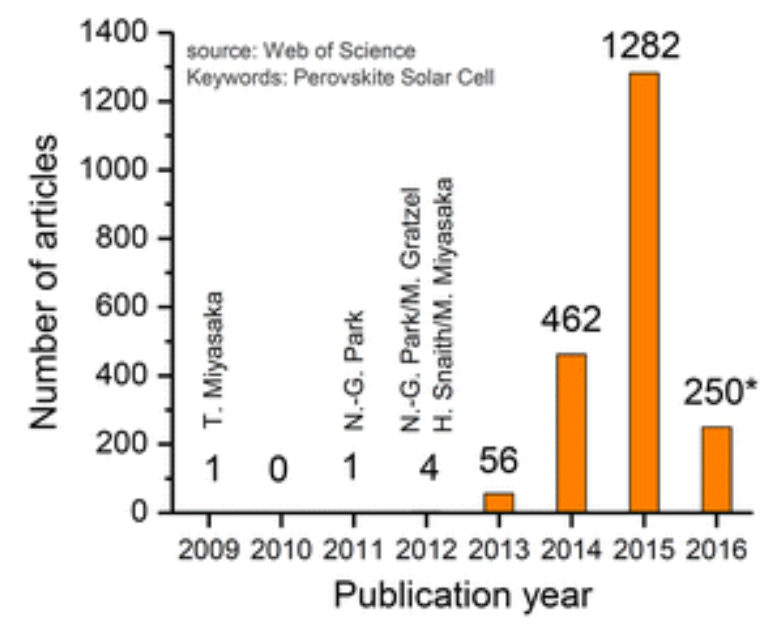

Figure 5: Summary of the Growth of PSC Since 2009 to 2016

Source: Nam-Gyu, 2016. 


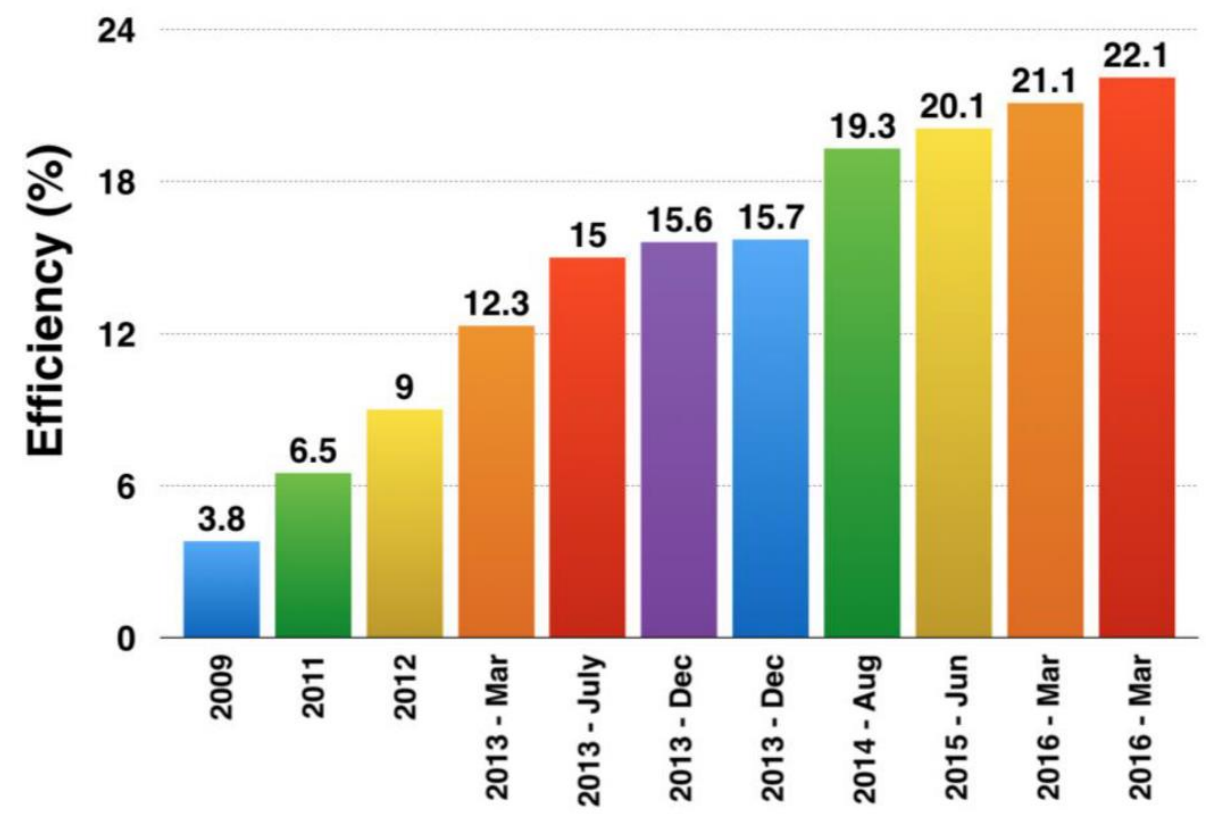

Figure 6: Reported Efficiencies of PSC Between 2009 and 2016

Source: Naveen et al. (2016).

\section{COMPARISON TO OTHER TECHNOLOGIES}

The advantage of Perovskite solar cells over existing solar technology lies within their excellent optical and electrical properties, low cost raw materials, facial film and device fabrication. It is anticipated that the demonstration of new solar technologies based on Perovskites, or the integration of an established manufacturing method that uses both Perovskite and existing technologies will be particularly promising for the future photovoltaic market (Song et al., 2015).

Perovskite materials have the potential to disrupt the current photovoltaic landscape owing to their unique use as an active layer in PV modules. This is so because Perovskites can deliver high open circuit voltages $\left(\mathrm{V}_{\mathrm{OC}}\right)$ under full sun illumination, leading to light harvesting from a broad spectrum of incident solar radiation. The fundamental loss in a solar cell which is the difference between $V_{\text {OC }}$ and the potential of the lowest energy photon generating a charge has been studied (Snaith, 2010). Snaith reported that thermodynamic treatment limits this loss to the tune of $250-300 \mathrm{meV}$, varying the band gap, based on Shockley-Queisser treatment. Onset of the IPCE spectrum determines the lowest energy absorbed photon. For $\mathrm{CH}_{3} \mathrm{NH}_{3} \mathrm{PbI}_{3-\mathrm{x}} \mathrm{Cl}_{2}$ Perovskite, the onset is $1.55 \mathrm{eV}$ $(800 \mathrm{~nm})$ with the best $\mathrm{V}_{\text {oc }}$ of 1.1 gives a loss in potential of $450 \mathrm{meV}$ which is lower than the reported loss of $0.59 \mathrm{eV}$ for best commercially available PV technology CdTe at an efficiency of $19.6 \%$ (Green et al., 2013). Thus, Perovskite solar cell, with the current state of the art, is at par with commercial technologies like CIGS, GeAs, and crystalline silicon.

Film formation of the absorber layer is the lay factor that determines the eventual performance of a PSC. The successful demonstration of high-performance Perovskite solar cells based on Mesoporous oxide scaffolds has proven the importance of the film quality, e.g. surface coverage and roughness, loading percentage, and crystallinity. However, a high temperature annealing process is needed to fabricate the Mesoporous scaffold which may increase the processing complexity and cost, and decrease the compatibility of implementing a high- 
performance flexible product, as well as integrating tandem cells into existing technologies; e.g. Si and CIGS modules.

Within a short span, Perovskites have demonstrated that they possess the right mix of properties to offer a solution to our energy needs (Muhammad et al., 2015). Though they evolved out of liquid electrolyte DSSCs, they are now established as a class of their own with extensive focused research pushing the efficiency limit beyond 20\%. Exploration of tandem cell configuration with Perovskite based cell as the top cell will push further the achievable efficacy limit. When the issues of stability and the use of lead is addressed, it can go a long way in maturing this technology for commercial application, though in the present legal framework, use of lead is not a problem as CdTe based solar cells has received wide acceptance despite Cd content (Muhammad et al., 2015). The use of lead extensively in lead acid batteries and its content at comparable levels in CIGS and silicon modules to Perovskites suggest that in the short term, the concern may not be pressing, but these technologies are increasingly being phased out and alternatives are explored to minimize the environmental impacts of these heavy metals. Noel et al. reported that the replacement of lead with tin in Perovskite solar cell is already under investigation and may offer an environment friendly alternative (Noel et al., 2014).

\section{CONCLUSION AND FUTURE OUTLOOK}

Advantages of PSCs which has captured tremendous attention are its; ability to fabricate large-scale transparent or semi-transparent flexible devices, simplicity of processing, easy optimization for structural design and material engineering; projected cost efficiency with superior PCE, longer electron / hole diffusion length, broad spectral absorption and high open circuit voltage, etc. With the amount of research effort underway, guided by the adherence to the issue of best practices, this technology holds great promise to addressing our energy needs in this present-day energy-starved nation, Nigeria. Balancing electron and hole transporting properties of PSCs, engineering its band gap, enhancing its fill factor either by doping or by improving its morphology, replacement of $\mathrm{Pb}$ with $\mathrm{Sn}$, use of mixed halogen Perovskites, use of composite of $\mathrm{TiO}_{2}$ and $\mathrm{Sb}_{2} \mathrm{~S}_{3}$, use of $\mathrm{TiO}_{2}$ free oxides, use of CNT polymer Nanocomposites, use of layered hybrid Perovskites, employing $\mathrm{NiO}$ as the p-type semiconductor, processability to improve HTL and ETL layer designs and the use of several different processing techniques such as Atomic layer deposition (ALD), high pressure pressing, chemical sintering, sol-gel and electrodeposition are known alternative optimization methods that can improve the efficiency and stability of PSCs devices. The solar industry should focus more on the quality and development of its technology.

Additionally, researchers should also focus on improving the competitiveness of solar power against both conventional and other renewable energy sources (Ehsanul et al., 2017). Hopefully, more research efforts will be dedicated toward PV technologies in the near future to enhance their efficiency, stability, manufacturability, and availability, to reduce balance-of-system (BOS) costs and reduce the costs of modules. Just recently, scientists in Hong Kong reported that they have successfully developed Perovskite-silicon tandem solar cells with the world's highest power conversion efficiency of $25.5 \%$.

It is recommended that the poor and incipient status of solar integration in the vastly populated Nigeria should be viewed in a positive light by potential foreign investors as such status is a guarantee that solar power and thermal industry is a firsthand investment opportunity (Ozoegwu et al., 2017). Solar energy resource is available in all parts of the country with an average sunshine hour of $5.535 \mathrm{KWh} / \mathrm{m}^{2} /$ day. Adekunle et al. (2015) carried out an analysis of global solar irradiance over climatic zones in Nigeria for solar energy applications. The 
authors found that generally, in all the climatic zones, coefficients of variation of solar radiation were high and mean values were low in July and August. Contour maps showed that high and low values of global solar irradiance and clearness index were observed in the Northern and Southern locations of Nigeria, respectively. The vast expanse of Sahel Savanna in the Northern region of Nigeria provides more than enough land space for this kind of project. According to Tunde et al. (2008), a yield of $5-20 \mathrm{~W} / \mathrm{m}^{2}$ is estimated for solar power. Assuming an area of about $300 \mathrm{Km}^{2}$ and at $10 \%$ solar panel efficiency; the power achievable:

$$
\begin{gathered}
=\left(5 \mathrm{~W} / \mathrm{m}^{2} \times 30 \times 10^{6} \mathrm{~m}^{2}\right) \text { to }\left(20 \mathrm{~W} / \mathrm{m}^{2} \times 30 \times 10^{6} \mathrm{~m}^{2}\right) \\
=150 \mathrm{MW}-600 \mathrm{MW} .
\end{gathered}
$$

This land space accounts for only about $0.03 \%$ of Nigeria's total land mass. Multiplying this land space by a factor of 10 gives a geometric feasibility of up to 6000MW of power. In addition, if one million homes in Nigeria own a $1000 \mathrm{~W}$ solar power system on their rooftops, the cumulative power production will be $7000 \mathrm{MW}$ of power which can add notably $45 \%$ to the present electricity consumption per capita.

In this review, we discuss the current state of the Art for photovoltaic devices based on Perovskites, highlighting the underlying phenomenon, synthesis, challenges, comparison to other technologies and future outlook. Accordingly, we conclude that despite a few drawbacks, solar energy technology is one of the most promising renewable energy sources to meet the future global energy demand. 


\section{REFERENCES}

Abbas, H., Kottokkaran, R., Balaji, G., Samie, M., Zhang, L. and Dalal, V. L. (2015). Highly efficient sequentially vapor grown n-i-p $\mathrm{CH}_{3} \mathrm{NH}_{3} \mathrm{PbI}_{3}$ Perovskite solar cells with undoped P3HT as p-type heterojunction layer, APL Materials. 3: 016105.

Abodunrin, T.J., Obafemi, O., Boyo, A.O., Adebayo, T. and Jimoh, R. (2015). The Effect of Electrolyte on Dye Sensitized Solar Cells Using Natural Dye from Mango (M. indica L.) Leaf as Sensitizer. Advances in Materials Physics and Chemistry, 5: 205-213. http://dx.doi.org/10.4236/ampc.2015.56021

Abrusci, A., Stranks, S. D., Docampo, P., Yip, H.L., Jen, A. K.Y and Snaith, H. J. (2013). High-performance Perovskite-polymer hybrid solar cells via electronic coupling with fullerene monolayers. Nano Letters. (13)7: 3124-3128.

Adaramola M. (2014). Solar energy: application, economics, and public perception. CRC Press, Technology \& Engineering.

Adekunle, A.O., Emmanuel, C.O., Stephen, B.O., and Olugbenga, F. (2015). Analysis of Global Solar Irradiance over Climatic Zones in Nigeria for Solar Energy Applications. Hindawi Publishing Corporation Journal of Solar Energy,9. http://dx.doi.org/10.1155/2015/819307

Akuru, U., Onukwube, E., Ifeanyichukwu, E., Okoro, O.I. and Obe, E. (2017). Towards 100\% renewable energy in Nigeria. Renewable and Sustainable Energy Reviews. (71): 943-953. 10.1016/j.rser.2016.12.123.

Bi, D., Moon, S. J., and H“aggman, L. (2013). Using a two-step deposition technique to prepare Perovskite $\left(\mathrm{CH}_{3} \mathrm{NH}_{3} \mathrm{PbI}_{3}\right)$ for thin film solar cells based on $\mathrm{ZrO}_{2}$ and $\mathrm{TiO}_{2}$ mesostructures. RSC Advances. (3)41: 18762-18766.

Burschka, J., Pellet, N., and Moon, S.J. (2013). Sequential deposition as a route to high-performance Perovskitesensitized solar cells. Nature, (499)7458: 316-319.

Chang-Jun L., Uwe B., Flemming B. and Zhong L.W. (2010). Characterization and Preparation of Nanomaterials for Sustainable Energy Production. Nano Focus. 4: 5517-5527.

Chiang, Y.F., Jeng, J.Y., Lee, M.H., Peng, S.R. and Hsu, C.M. (2014). High voltage and efficient bilayer heterojunction solar cells based on an organic-inorganic hybrid Perovskite absorber with a low-cost flexible substrate. Advances in Materials Physics and Chemistry. 6: 6033-6040.

Dawn, J. M. (2016). An introduction to Perovskite solar cells (PSCs). ECE. University of British Columbia Vancouver. Retrieved on July $4^{\text {th }} 2017$ from https://www.researchgate.net/publication/303541142

Docampo, P., Ball, J. M., Darwich, M., Eperon, G. E. and Snaith, H. J. (2013). Efficient organometal trihalide Perovskite planar heterojunction solar cells on flexible polymer substrates. Nature Communications. (4) 2761

Ehsanul K., Pawan K., Sandeep K., Adedeji A. A., and Ki-Hyun K. (2017). Solar energy: Potential and future prospects. Elsevier Journal on Renewable and Sustainable Energy Reviews, (82)2018: 894-900. http://dx.doi.org/10.1016/j.rser.2017.09.094

Elano S., Guillermo R. and Javier G. (2009). Nanotechnology for Sustainable Energy. Renewable and Sustainable Energy Review. (5)4: 2337-2384.

Eperon, G.E., Burlakov, V.M., Docampo P., Goriely A. and Snaith, H.J. (2013). Morphological Control for High Performance, Solution-Processed Planar Heterojunction Perovskite Solar Cells. Advanced Functional Materials 24: 151-157. Available: http://dx.doi.org/10.1002/adfm.201302090.

Eperon, G.E., Burlakov, V.M., Docampo, P., Goriely, A. and Snaith, H.J. (2014). Morphological control for high

13 | lyasele, 2020 
performance, solution-processed planar heterojunction Perovskite solar cells. Advanced Functional Materials, (24)1: 151- 157.

Espinosa, N., Hosel, M., Angmo, D., and Krebs, F.C. (2012). Solar cells with one-day energy payback for the factories of the future. Energy Environmental Science. 5: 5117-5132.

Ezike, C., Kana, G., \& Aina, A. (2017). Progress and Prospect on Stability of Perovskite Photovoltaics. Journal of Modern Materials, (4)1 :16-30. doi: https://doi.org/10.21467/jmm.4.1.16-30

Green, M. A., Emery, K., Hishikawa, Y., Warta, W., and Dunlop, E. D. (2012). Solar cell efficiency tables (version 40). Progress in Photovoltaics: Research and Applications, (20)5: 606- 614.

Green, M. A., Ho-Baillie, A. and Snaith, J. (2014). The emergence of Perovskite solar cells. Nature Photon. 8: 506-514.

Guarnera, S., Abate, A., and Zhang, W. (2015). Improving the long-term stability of Perovskite solar cells with a porous $\mathrm{Al}_{2} \mathrm{O}_{3}$ buffer layer. The Journal of Physical Chemistry Letters, (6)3: 432-437.

Habisreutinger, S.N., Leijtens, T., Eperon, G.E., Stranks, S.D., Nicholas, R.J. and Snaith, H.J. (2014). Carbon nanotube/polymer composites as a highly stable hole collection layer in Perovskite solar cells. Nano Letters, (14)10: 5561-5568.

$\mathrm{Hu}, \mathrm{H}$., Wang, D. and Zhou, Y. (2014). Vapour-based processing of hole-conductor-free $\mathrm{CH}_{3} \mathrm{NH}_{3} \mathrm{PbI}_{3}$ Perovskite/C60 fullerene planar solar cells, RSC Advances, (4)55 : 28964- 28967.

Im, J.H., Kim, H.S. and Park, N.G. (2014). Morphology-photovoltaic property correlation in Perovskite solar cells: One-step versus two-step deposition of $\mathrm{CH}_{3} \mathrm{NH}_{3} \mathrm{PbI}_{3}$. APL Materials, (2)081510. https://doi.org/10.1063/1.4891275

Ito, S., Tanaka, S., Vahlman, H., Nishino, H., Manabe, K. and Lund, P. (2014). Carbon-double-bond-free printed solar cells from $\mathrm{TiO} 2 / \mathrm{CH}_{3} \mathrm{NH}_{3} \mathrm{PbI}_{3} / \mathrm{CuSCN} / \mathrm{Au}$ : structural control and photoaging effects. ChemPhysChem. 15: 1194-1200.

Jeng, J.Y., Chiang, Y.F., and Lee, M.H. (2013). $\mathrm{CH}_{3} \mathrm{NH}_{3} \mathrm{PbI}_{3}$ Perovskite/fullerene planar-heterojunction hybrid solar cells. Advanced Materials. (25)27: 3727-3732.

Jianqing, C., Xin, C., Donghui, Y., Dan, S., Jiajia, W., Jinghua, J. and Chaoying, N. (2017). Recent progress in stabilizing hybrid Perovskites for solar cell applications. Journal of Power Sources, 355 : 98-133.

Kesinro, O.R., Akinyemi, M.L. and Boyo, A.O. (2017). Advances in Perovskite-Based Solar Cells for the Proceedings of International Conference on Science and Sustainable Development (ICSSD) "The Role of Science in Novel Research and Advances in Technology" Center for Research, Innovation and Discovery, Covenant University, Nigeria. Journal of Informatics and Mathematical Sciences (9)2 : 485-491.

Kim, H., Lee, C., Im, J., Lee, K., Moehl, T., Marchioro, S. M. and Park, N. (2012). Lead Iodide Perovskite Sensitized All-Solid-State Submicron Thin Film Mesoscopic Solar Cell with Efficiency Exceeding 9\%. Scientific Report. 2: 591; DOI:10.1038/srep00591

Kim, H.S., Lee, C.R., Im, J.H., Lee, K.B. and Park, N.G. (2012). Lead iodide Perovskite sensitized allsolid-state submicron thin film mesoscopic solar cell with efficiency exceeding 9\%. Scientific Reports, 2: 591

Kim, H.S., Im, S.H. and Park, N.G. (2014). Organolead halide Perovskite: new horizons in solar cell research. Journal of Physical Chemistry C, (118)11: 5615-5625.

Kim, B.J., Kim, D.H., and Lee, Y. (2015). Highly efficient and bending durable Perovskite solar cells: toward a wearable power source. Energy \& Environmental Science, (8)3 : 916-921. 
Kojima, A., Teshima, K., Miyasaka, T., and Shirai, Y. (2006). Novel photoelectrochemical cell with mesoscopic electrodes sensitized by lead-halide compounds, in: 210 ${ }^{\text {th }}$ ECS Meeting, Cancun, Mexico, p. 397.

Kojima, A., Teshima, K., Shirai, Y. and Miyasaka, T. (2008). Novel photoelectrochemical cell with mesoscopic electrodes sensitized by lead-halide compounds (11). ECS Meeting. vol. 27, abstract MA2008-02.

Kojima, A., Teshima, K., Shirai, Y. and Miyasaka, T. (2009). Organometal halide Perovskites as visible-light sensitizers for photovoltaic cells. Journal of American Chemistry Society. 131: 6050-6051.

Kumar, M.H., Yantara, N., Dharani, S. Graetzel, M., Mhaisalkar, S., Boix, P.P. and Mathews, N. (2013). Flexible, low-temperature, solution processed ZnO-based Perovskite solid state solar cells. Chemical Communications, 49: 11089-11091.

The Hong Kong Polytechnic University. Perovskite-silicon tandem solar cells with the world's highest power conversion efficiency. ScienceDaily. Retrieved on August 14 ${ }^{\text {th }} 2016$ from: www.sciencedaily. com/releases/2016/04/160412104814.htm.

Tunde, O., Titilayo, A., Kunle, A., Femi, O. and Adelana, A. (2016). Energy Crisis in Nigeria: Need for Renewable

Energy Mix. American Journal of Electrical and Electronic Engineering, (4)1 : 1-8. doi: 10.12691/ajeee-4-1-1.

Lee, M.M., Teuscher, J., Miyasaka, T., Murakami, T.N. and Snaith, H.J. (2012). Efficient hybrid solar cells based on meso-superstructured organometal halide Perovskites. Science. 338: 643-647.

Leijtens, T., Eperon, G.E., Pathak, S., Abate, A., Lee, M.M. and Snaith, H.J. (2013). Overcoming ultraviolet light instability of sensitized $\mathrm{TiO}_{2}$ with meso-superstructured organometal trihalide Perovskite solar cells. Nature Communications. 4: 2885

Li, C., Lu, X., Ding, W., Feng, L., Gao, Y. and Guo, Z. (2008). Formability of $\mathrm{ABX}_{3}(\mathrm{X}=\mathrm{F}, \mathrm{Cl}, \mathrm{Br}, \mathrm{I})$ halide Perovskites. Acta Crystallographica B, 64: 702-707.

Li, W., Dong, H., Wang, L., Li, N., Guo, X., Li, J. and Qiu, Y. (2014). Montmorillonite as bifunctional buffer layer material for hybrid Perovskite solar cells with protection from corrosion and retarding recombination. Journal of Materials Chemistry A, 2: 13587-13592.

Liang, P. W., Liao, C. Y., Chueh, C. C., Zuo, F., Williams, S. T., Xin, X. K., Lin, J. and Jen, A. K. Y. (2014). Additive enhanced crystallization of solution-processed Perovskite for highly efficient planarheterojunction solar cells. Advance Materials, 26 : 3748-3754.

Liu, M., Johnston, M.B., Snaith, H.J. (2013). Efficient Planar heterojunction Perovskite Solar Cells by vapour deposition, Nature, 501: 395-398.

Liu, D. and Kelly, T.L. (2014). "Perovskite solar cells with a planar heterojunction structure prepared using roomtemperature solution processing techniques," Nature Photonics, (8)2: 133-138.

Liu, S., Zheng, F., Koocher, N.Z., Takenaka, H., Wang, F. and Rappe, A.M. (2015). "Ferroelectric domain wall induced band gap reduction and charge separation in organometal halide Perovskites," The Journal of Physical Chemistry Letters, (6)4: 693-699.

Luther M. and Ranjit T. K. (2014). Versatility of Evaporation-Induced Self-Assembly (EISA) Method for Preparation of Mesoporous $\mathrm{TiO}_{2}$ for Energy and Environmental Applications. Materials, 7: 2697-2746; doi:10.3390/ma7042697. ISSN 1996-1944. Retrieved on December 2017 from: www.mdpi.com/journal/materials

Mailoa, J. P., Bailie, C. D. and Johlin, E. C. (2015). A 2-terminal Perovskite/silicon multijunction solar cell enabled by a silicon tunnel junction. Applied Physics Letters. (106)12: 121105. 
Malinkiewicz, O., Yella, A. and Lee, Y.H. (2014). Perovskite solar cells employing organic charge-transport Layers. Nature Photonics, (8)2: 128-132.

Mao S.S. and Xiaobo C. (2007). Selected Nanotechnology for Renewable Energy Applications. International Journal on Energy and Research. 31: 619-636.

Mei, A., Li, X., Liu, L., Ku, Z., Liu, T...... and Han, H. (2014). A hole-conductor-free, fully printable mesoscopic Perovskite solar cell with high stability. Science, 345 : 295-298.

Muhammad, I. A., Amir, H., and Syed, S. J. (2015). Perovskite Solar Cells: Potentials, Challenges, and Opportunities. Hindawi Publishing Corporation International Journal of Photoenergy,

(2015) 13 doi : 10.1155/2015/592308

Nam-Gyu, P. (2016). Methodologies for high efficiency Perovskite solar cells. Nano Convergence, 3:15-??? doi: 10.1186/s40580-016-0074-X

National Geographic Report (2017). Title???? Retrieved on October $2^{\text {nd }} 2017$ from: http://www.nationalgeographic.com/environment/global-warming/solar-power.html.

Naveen, K. E., Md, A. M., Dian, W. and Ashraf, U. (2016). Perovskite Solar Cells: Progress and Advancements. Energies, 9 : 861-???; doi:10.3390/en9110861

Noel, N.K., Stranks, S.D. and Abate, A. (2014). Lead-free organic-inorganic tin halide Perovskites for photovoltaic applications. Energy and Environmental Science. (7)9 : 3061-3068.

Noh, J.H., Jeon, N.J., Choi, Y.C., Nazeeruddin, M.K., Gr“atzel, M. and Seok, S.I. (2013). Nanostructured $\mathrm{TiO}_{2} / \mathrm{CH}_{3} \mathrm{NH}_{3} \mathrm{PbI}_{3}$ heterojunction solar cells employing spiro-OMeTAD/Co-complex as hole-transporting Material. Journal of Materials Chemistry A, (1)38 : 11842-1184.

Olopade, M. A., Oyebola, O. O., Adewoyin, A. D., Emi-Johnson, D. O. (2015). Modeling and Simulation of CZTS/CTS Tandem Solar Cell using wxAMPS Software. Department of Physics, University of Lagos, Akoka, Lagos, Nigeria. 978-1-4799-7944-8/15@IEEE.

Pang, S., Hu, H., Zhang J., Lv, S., Yu, Y., Wei, F., Qin, T. and Cui, G. (2014). $\mathrm{NH}_{2} \mathrm{CH}=\mathrm{NH}_{2} \mathrm{PbI}_{3}$ : an alternative organolead iodide Perovskite sensitizer for mesoscopic solar cells. Chemistry of Materials, (26)3: 1485-1491. Doi: 10.1021/cm404006p

Paola, V., Jagadish, K. S., and Arri, P. (2017). Hole-Transporting Materials for Printable Perovskite Solar Cells. Materials, 10: 1087-????; doi:10.3390/ma10091087

Pathak, S.K., Abate, A. and Leijtens, T. (2014). Towards long-term photostability of solid-statedy esensitized solar cells. Advanced Energy Materials. (4)8: 1301667.

Pellet, N., Gao, P., Gregori, G., Yang, T.Y., Nazeeruddin, M.K., Maier, J. and Gratzel, M. (2014). Mixed-organiccation Perovskite photovoltaics for enhanced solar-light harvesting. Angewandte Chemie International Edition in English. 53: 3151-3157.

Rong, L., Liu, L., Mei, A., Li, X., and Han, H. (2015). Beyond efficiency: the challenge of stability in mesoscopic Perovskite solar cells. Advance Energy Materials. 5: 1501066.

Seelam. P. and Lingamallu, G. (2016). Recent advances in Perovskite-based solar cells. Current Science, (3)7 doi: 10.18520/cs/v111/I7/1173-1181

Service, R.F. (2014). Energy technology: Perovskite solar cells keep on surging. Science, (344)6183 - 458.

Shiqiang L. and Walid A. D. (2016). Crystal Structure Formation of $\mathrm{CH}_{3} \mathrm{NH}_{3} \mathrm{PbI}_{3-\mathrm{x}} \mathrm{Cl}_{\mathrm{x}}$ Perovskite. MDPI Materials, 9: 123-????; doi:10.3390/ma9030123

Smith, I.C., Hoke, E.T., Solis-Ibarra, D., McGehee, M.D. and Karunadasa, H.I. (2014). A Layered Hybrid 
Perovskite Solar-Cell Absorber with Enhanced Moisture Stability. Angewandte Chemie International Edition in English, (126)42-48

11414-11417, DOI: 10.1002/ange.201406466

Snaith, H.J. (2010). "Estimating the maximum attainable efficiency in dye-sensitized solar cells. Advanced Functional Materials (20)1: 13-19.

Snaith, H.J. (2013). Perovskites: the emergence of a new era for low-cost, high-efficiency solar cells. Journal of Physical Chemistry Letters, 4: 3623 - 3630.

Snaith, H.J., Abate, A., and Ball, J.M. (2014). “Anomalous hysteresis in Perovskite solar cells. Journal of Physical Chemistry Letters, (5)9: 1511-1515.

Song, T., Chen, Q., Zhou, H., Jiang, C., Wang, H., Yang, Y., Liu, Y., You, J., and Yang, Y. (2015). Perovskite solar cells: film formation and properties. Journal of Materials Chemistry A, Retrieved on January $5^{\text {th }}$ 2017 from http://www.rsc.org/materialsA

Stoumpos, C.C., Malliakas, C.D. and Kanatzidis, M.G. (2013). Semiconducting tin and lead iodide Perovskites with organic cations: phase transitions, high mobilities, and near-infrared photoluminescent properties. Inorganic Chemistry, (52)15: 9019-9038.

Ugwoke, L. C. (2014). Limiting Efficiency of Perovskite Solar Cells an Unpublished M.Sc. Thesis presented to the Department of Theoretical Physics, African University of Science and Technology (AUST), Abuja, Nigeria.

Unger, E.L., Hoke, E.T., and Bailie, C.D. (2014). Hysteresis and transient behavior incurrent-voltage measurements of hybrid Perovskite absorber solar cells. Energy and Environmental Science, (7)1 : 3690-3698.

Wang, D., Wright, M., Elumalai, K.N., and Uddin, A. (2016). Stability of Perovskite solar cells. Solar Energy Materials and Solar Cells. 147: 255-275. http://dx.doi.org/10.1016/j.solmat.2015.12.025

World Energy Council, (2016). World Energy Resources Report. Retrieved on January $12^{\text {th }} 2018$ from (https://www.worldenergy.org/publications/2016/world-energy-resources-2016/)

www.sciencedaily. com/releases/2016/04/160412104814.htm [Retrieved on January $12^{\text {th }}, 2018$ ]

Xiao, Z., Bi, C. and Shao, Y. (2014). Efficient, high yield Perovskite photovoltaic devices grown by inter diffusion of solution-processed precursors tacking layers. Energy \& Environmental Science, (7)8 : 2619-2623.

Xu, Q.Y., Yuan, D.X., Mu, H.R., Femi, I., Bao, Q., and Liao, L.S. (2016). Efficiency Enhancement of Perovskite Solar Cells by Pumping Away the Solvent of Precursor Film Before Annealing. Nanoscale Research Letters, 11: 248 doi : 10.1186/s11671-016-1467-9

Yang, W. S. (2015). High-performance photovoltaic Perovskite layers fabricated through intramolecular exchange. Science, 348: 1234-1237.

You, J., Hong, Z., Yang, Y., Chen, Q., Cai, M. and Yang, Y. (2014). Low-temperature solution-processed Perovskite solar cells with high efficiency and flexibility. ACS Nano, 8 : 1674-1680.

Yu, Z. and Sun, L. (2015). Recent progress on hole-transporting materials for emerging organometal halide Perovskite solar cells. Advance Energy Materials. 5: 1500213.

Zhang, W. et al. (2015). Ultrasmooth organic-inorganic Perovskite thinfilm formation and crystallization for efficient planar heterojunction solar cells. Nature Communication, 6: 6142.

Zhou, H., Chen, Q. and Li, G. (2014). Interface engineering of highly efficient Perovskite solar cells. Science, (345)196: 542-546 